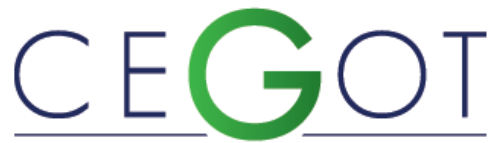

Centro de Estudos de Geografia e Ordenamento do Território
GUIMARÃES, SÁVIO

Centro Universitário de Brasília, Faculdade de Tecnologia e Ciências

Sociais Aplicadas

707/907, Brasília, Brasil.

savio.guimaraes.2010@gmail.com

\title{
Parques públicos urbanos: proposições e desdobramentos entre os contextos industrial e pós-industrial.
}

Urban public parks: proposals and developments between the industrial and post-industrial contexts.

Referência: Guimarães, Sávio (2020). Parques públicos urbanos: proposições e desdobramentos entre os contextos industrial e pós-industrial. Revista de Geografia e Ordenamento do Território (GOT), n.ㅇ 20 (Dezembro). Centro de Estudos de Geografia e Ordenamento do Território, p. 221-252, dx.doi.org/10.17127/got/2020.20.010

\section{RESUMO}

Ainda que os parques públicos urbanos sejam, geralmente, marcados pelos elementos naturais que configuram seu paisagismo, ainda que se destaque seu vínculo às atividades de lazer e esporte, fruição estética e ócio, seu estudo os evidencia como equipamentos portadores de dimensões de conhecimento que ultrapassam, em muito, suas características mais aparentes e sua assimilação superficial. A presente investigação deste tema partiu de um recorte abrangente, do contexto industrial ao pós-industrial, permissível a reflexões sobre esses sistemas espaciais em suas mais distintas realizações. Já a metodologia engendrada para tal estudo foi permeada por três orientações: inicialmente, sendo ancorada em referenciais bibliográficos que envolvem o objeto de investigação, em seguida, se apoiando em visitações de caráter observacional e registros fotográficos de parques realizados durante um longo período já dedicado à exploração do tema e, por fim, ressaltando casos selecionados por representarem tipos emblemáticos desses equipamentos que, mesmo localizados em diferentes continentes e contextos socioaculturais distintos, no entrecruzar de suas realidades e dinâmicas, permitem o estabelecimento de especulações comparativas que instigam sua análise e iluminam sua interpretação. A abordagem dialética assim adotada na estruturação e desenvolvimento do estudo permitiu explicitar as múltiplas dimensões e o caráter dinâmico que envolvem os parques urbanos em meio a intenções e estratégicas, projetos e espacializações, usos e desdobramentos distintos.

Palavras-chave: Parques públicos urbanos; paisagismo; cidade industrial; cidade pós-industrial. 


\section{ABSTRACT}

Although public urban parks are generally marked by the natural elements that make up their landscaping, although their connection to leisure and sport activities, to aesthetic enjoyment and idleness stands out, their study shows them as facilities holding dimensions of knowledge that far exceed their most apparent characteristics and their superficial assimilation. The present investigation of this theme started with a comprehensive snapshot, from the industrial to the post-industrial context, allowable when thinking over these spatial systems in a great variety of achievements. The methodology created for this study was intertwined with guiding lines: initially, based on a bibliographical review related to the object of investigation; then, based on observational visits and photographs of parks taken during a long period when the theme was already being explored, and finally, highlighting selected cases which represent emblematic types of facilities that, even located in different continents and different socio-cultural contexts, in the intersection of their realities and dynamics, make room for comparative speculations that instigate their analysis and shed light on their interpretation. The dialectical approach adopted in structuring and conducting the study made it possible to explain the multiple dimensions and the dynamic nature involving urban parks in the midst of a variety of intentions and strategies, projects and spatializations, uses and developments.

Keywords: Urban public parks; landscaping; industrial city; post-industrial city.

\section{Introdução}

Objetivando organizar o pensamento sobre uma gama de espaços interrelacionados, aqui abordados sob a denominação abrangente de parques públicos urbanos, o presente artigo foi estruturado sob um recorte extenso que corresponde há quase dois séculos, mas que se mostra pertinente por abranger dois momentos históricos permissíveis a uma análise que perpassa das primeiras às mais recentes experimentações desse sistema ou categoria espacial. Especificamente, a presente abordagem ressalta a temática desses elementos urbanos multidimensionais difundidos nas mais diversas cidades, seja no contexto industrial, vivido entre os séculos XVIII e XX, seja no contexto pós-industrial, assim caracterizado, desde meados do século XX, como um novo momento histórico.

A partir desses dois momentos históricos adotados como base para a análise, a abordagem dos mesmos, construída sob referencial bibliográfico, foi ancorada na realidade pela seleção de exemplares de parques públicos urbanos emblemáticos surgidos em ambos os contextos, situados nos mais distintos continentes, sob suas realidades socioaculturais dinâmicas que, por tudo isso, se mostraram favoráveis a comparações e ao reconhecimento de paradigmas e singularidades. Ora históricos ora contemporâneos, casos como o dos parques analisados 
perfazem, por sua história, por sua vivência continuada e registro de seus instantes, elementos fundamentais na compreensão do sistema espacial que representam e que este artigo investiga a partir de suas múltiplas dimensões interpretativas.

Sob essa estruturação do artigo, considerada pertinente para uma maior aproximação da temática em estudo, a abordagem se desenvolveu destacando, sobretudo, que os parques, como qualquer outro espaço, são resultantes de suas influências pregressas e suas atualizações sucessivas, produzidas por inter-relações sociais, ou seja, fruto de negociações sempre em processo. Assim, sob esse entrelaçamento de perspectivas de análise, em meio a intenções e estratégicas, projetos e espacializações, usos e desdobramentos distintos identificados no contexto que envolve os mais variados parques urbanos, o artigo perpassa questões que se diversificam: entre estratégias de higienização urbana e controle social, modernização espacial e dispositivos paisagísticos, inovação artística e resistência cultural, economia e sustentabilidade, além de dar margem a outras possíveis correlações também passíveis de consideração sobre este tema e seus múltiplos sentidos.

\section{Parques públicos urbanos entre dimensões interpretativas}

[...] Salve o verde / salve o verde / Deus salve o verde / que o homem está acabando / e construindo o cinza / salve o verde / salve o verde / tá faltando grama / neste jardim / tá faltando árvore / nesta cidade / tá faltando oxigênio / nesta atmosfera / o que será / o que será / o que será / o que será da biosfera? (BENJOR, 1978).

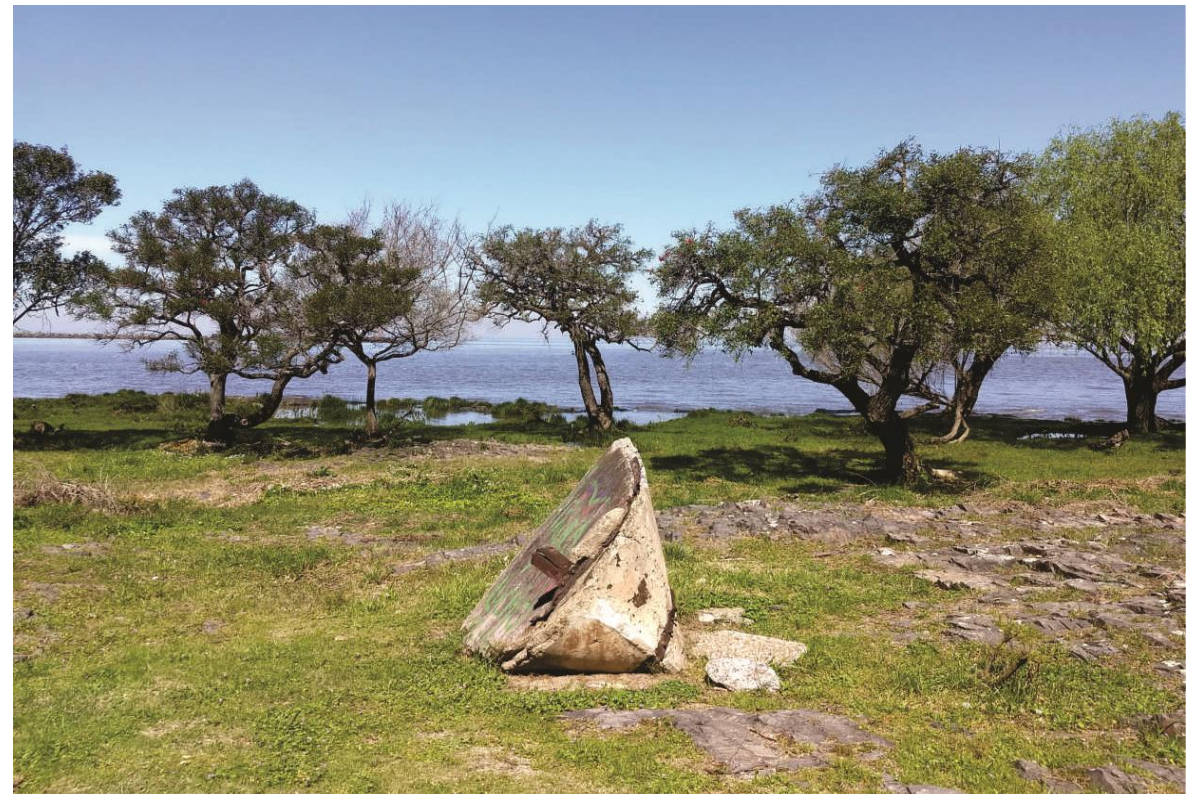

Fig. 1 - Park Lineal Administración de Ferrocarriles del Estado, em Colônia de Sacramento/Uruguai. Fonte: Acervo pessoal do autor (2017). 
Parque, jardim, praça, passeio público, alameda, boulevard, cour, mall, entre outros termos, são algumas das denominações utilizadas historicamente para designar espacialidades que, apesar de suas especificidades, podem ser correlacionadas, sobretudo, pelas interações que promovem em um mesmo sistema socioterritorial (FERNANDES, 2005), configurado, geralmente, pela manipulação de elementos naturais em áreas livres integradas à estrutura operacional das cidades para usos diversos (Fig. 1). Se considerarmos os espaços a partir de influências anteriores associaidas ao contexto das inter-relações sociais que os produz e os atualiza sucessivamente por proposições, imposições ou negociações, mantendo-os sempre em processo (LEFEBVRE, 2013; MASSEY, 2008), os parques públicos urbanos permitem, e instigam, por sua configuração espacial híbrida em vários aspectos, análises que perpassam suas múltiplas dimensões interpretativas.

Sobre a dimensão de temporalidade, aqui centrada em dois contextos históricos, cabe ressaltar, inicialmente, no que se refere ao primeiro contexto abordado, o fato de a industrialização, ao engendrar transformações sem precedentes no âmbito das cidades, desde suas primeiras manifestações no continente europeu, levou a esfera urbana a alcançar uma hegemonia sem precedentes até então, tendo, entre seus destaques, justamente, os parques públicos. Afinal, se deu em tal contexto a difusão desses equipamentos urbanos entre estratégias e aspirações de caráter variado, adotadas como respostas à nova realidade de ritmo veloz irrompida com os processos de modernização da produção que, a partir desse novo parâmetro ocidental, reorganizaram mundialmente conjunturas distintas, forjando uma "sociedade industrial" (MARCUSE, 1973) e um momento histórico específico, aqui enunciado como "contexto industrial".

Igualmente instigante a reflexões sobre o espaço público, o subsequente "contexto pósindustrial", assim enunciado por corresponder a um momento marcado por diferenças significativas em relação ao contexto industrial, expressa, por sua vez, as peculiaridades de uma "sociedade pós-industrial" (BELL, 1977), caracterizada menos pela produção industrial e, mais notadamente, pelo oferecimento de serviços, como conhecimentos capitalizados postos em circulação global através das atuais tecnologias de informação e comunicação. Decerto, imersos nesse novo contexto, ainda de difícil definição por se encontrar em curso, susceptível a ajustes constantes, se mostram pertinentes os esforços de reflexão sobre a esfera urbana contemporânea e seus espaços emblemáticos como, novamente, os parques, 
portadores de significados específicos em suas ambiências inovadoras ou reconfiguradas por recairem sobre elas, também agora, os mais diversos interesses e expectativas (Fig. 2).

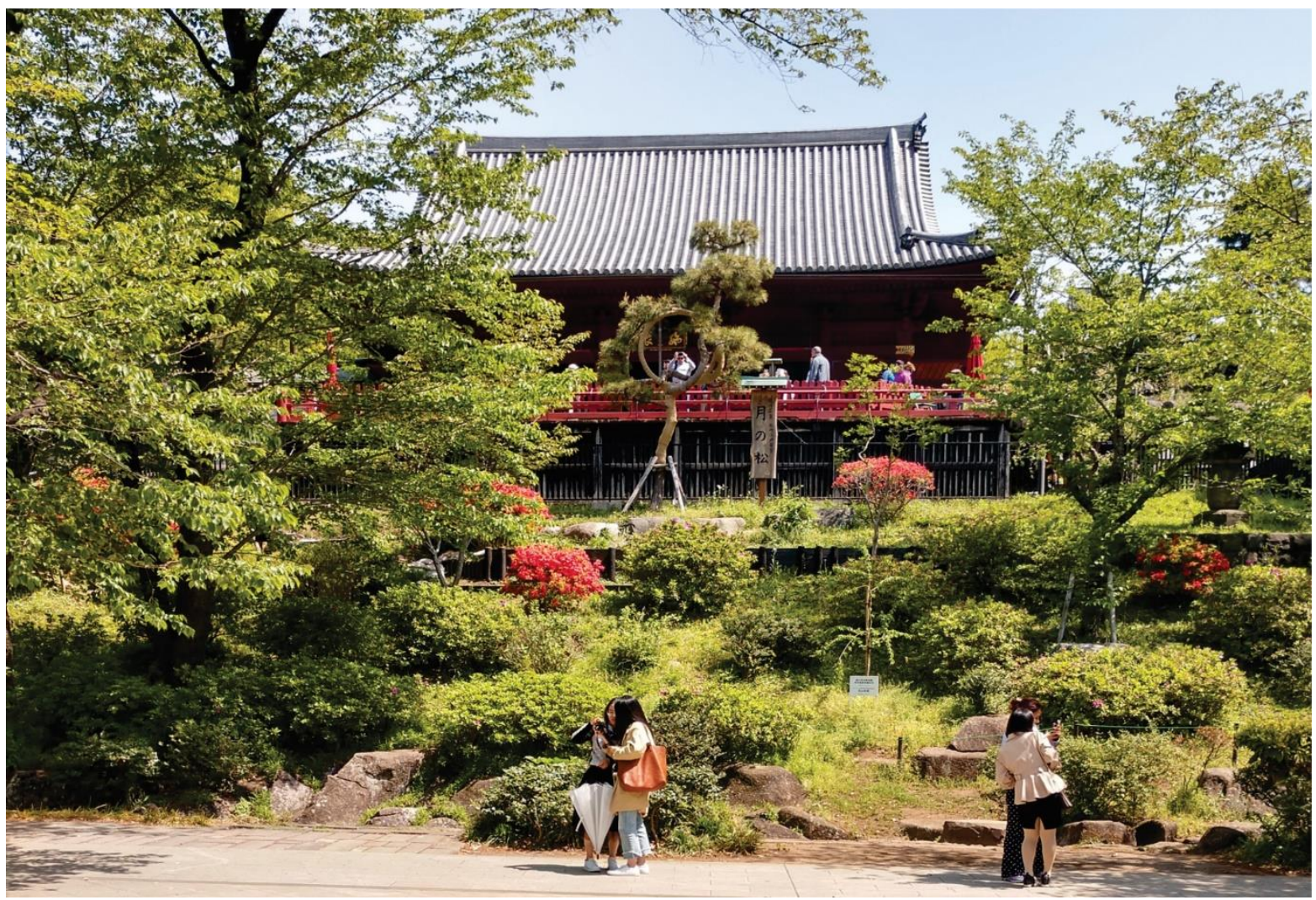

Fig. 2 - Parque Ueno em Tóquio/Japão.

Fonte: Acervo pessoal do autor (2018).

Sob essas bases iniciais a argumentação se construiu sob a percepção de outras dimensões, as espaciais (ZEVI, 1986; COUTINHO, 2010), fundamentais em uma reflexão sobre esse campo. A percepção de destaques específicos geralmente dados a algumas das múltiplas dimensões de um parque em sua assimilação, tanto pela literatura crítica quanto pela divulgação dos mesmos, estimulou semelhante ênfase na abordagem aqui desenvolvida sobre parques criados no contexto industrial e no pós-industrial, ainda que se considere aqui a correlação existente entre essas dimensões em qualquer parque. Desse modo, o artigo evidencia, em cada um desses dois contextos, a dimensão paisagística, a "porção" de um território (SANTOS, 2008) que a princípio se acentua como essência de qualquer parque; assim como evidencia a dimensão conceitual que, como em espaços de outras categorias, pode envolver intenções e desdobramentos diversos a partir da formulação de uma "ideia" em projeto (MONEO, 2008); além de evidenciar, ainda, a dimensão heterotópica, que se 
ressalta nas múltiplas "camadas" de significação de um espaço (FOUCAULT, 2009) e que pode ser constatada, seja nos parques históricos, que já experimentaram alterações de acomodação e ajuste às demandas emergentes com as dinâmicas do tempo, seja nos novos parques surgidos sob alusões à história ou mesmo pela reconfiguração de equipamentos urbanos pré-existentes ampliando o conjunto de significados ali agregados (Fig. 3).

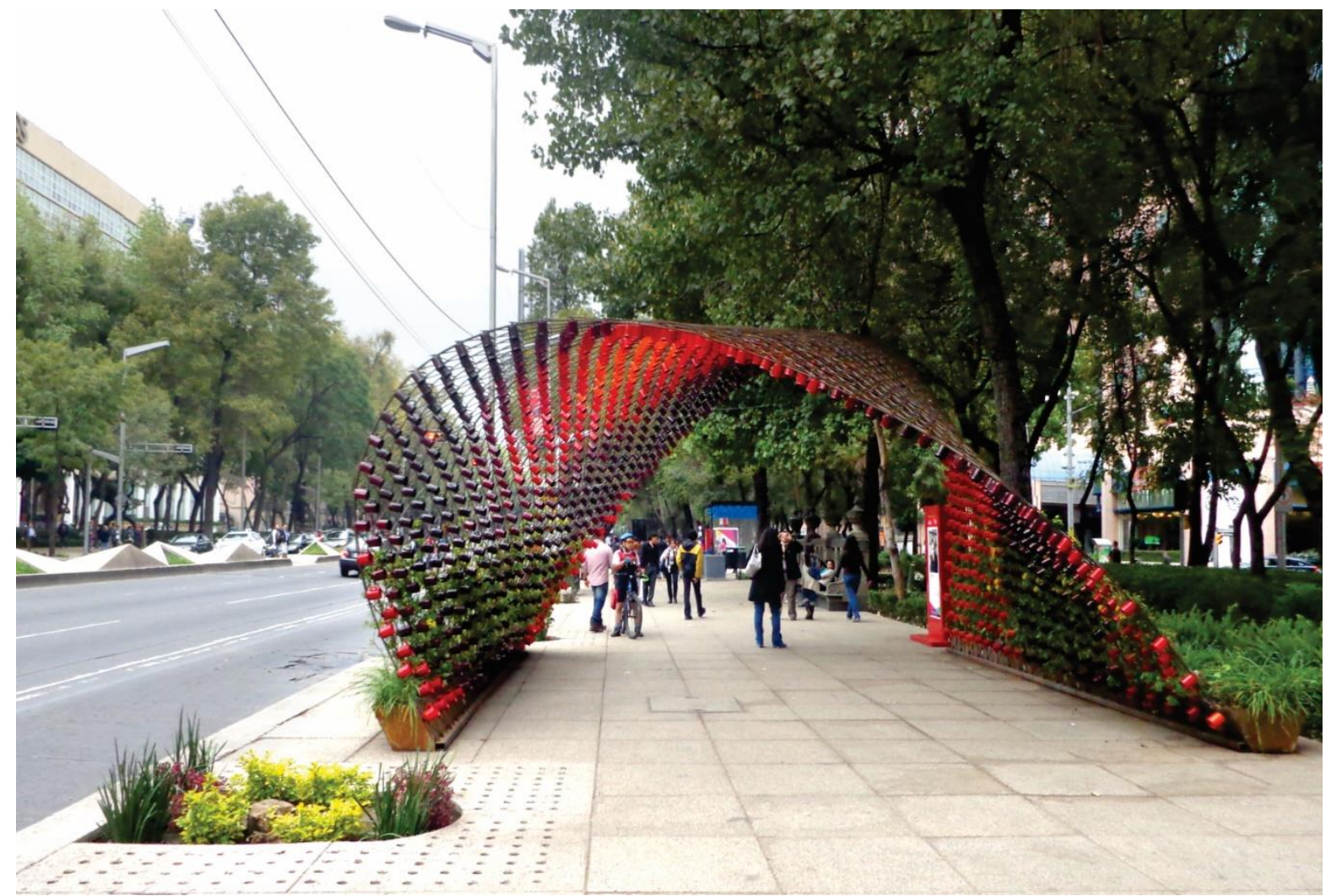

Fig. 3 - Paseo de la Reforma na Cidade do México/México.

Fonte: Acervo pessoal do autor (2012).

Todavia, além dessas três dimensões espaciais estruturadoras da argumentação sobre os parques surgidos nos dois contextos em questão, outras dimensões também conformadoras de um espaço e de suas correlações se revelam ao longo da abordagem delineando seu conhecimento e interpretação como um apoio enriquecedor. Assim sendo, a análise dos parques aqui considerados a partir de seus contextos de criação, também perpassa, por exemplo, suas dimensões historico-cultural, político-econômica e de apropriação e utilização pelos cidadãos em suas interações com a natureza e o espaço público no meio urbano.

Em seu conjunto, essas múltiplas dimensões de interpretação, que partem do equipamento urbano representado pelos parques, levam a reflexões mais amplas - pelas expectativas, 
cristalizações, assimilações, dinâmicas e gestão de seus processos dinâmicos, promotores de interfaces com outros espaços urbanos. Ressalta-se, assim, o papel dos parques tanto na construção da cidade, no que se refere a seu planejamento e ao ordenamento de seu território, quanto no exercício da cidadania, no que se refere ao direito à cidade sob as perspectivas de fruição espacial, liberdade de expressão e convívio social em seus espaços livres e de acesso público. De facto, o conceito de cidadania, ampliado historicamente a partir das noções de bem comum e de igualdade como direitos que já vão além dos civis, sociais e políticos, encontra, nas amplas áreas livres urbanas, como a dos parques públicos, um cenário significativo para seu exercício. Um exercício que, desde o declínio do Estado de bem-estar social na década de 1980 à crise sanitária exponenciada também em escala global pela pandemia de 2020, vem se transfigurando, seja por abalos sucessivos em direitos previamente adquiridos, seja pelas conseqüentes resistências, reivindicações, aspirações e ações mitigadoras das assimetrias socioeconômias e das questões ambientais intensificadas.

\section{Parques públicos urbanos surgidos no contexto industrial}

[...] Tropeçando em palavras como nas calçadas / Topando imagens desde há muito já sonhadas (BAUDELAIRE, 1985, p. 319).

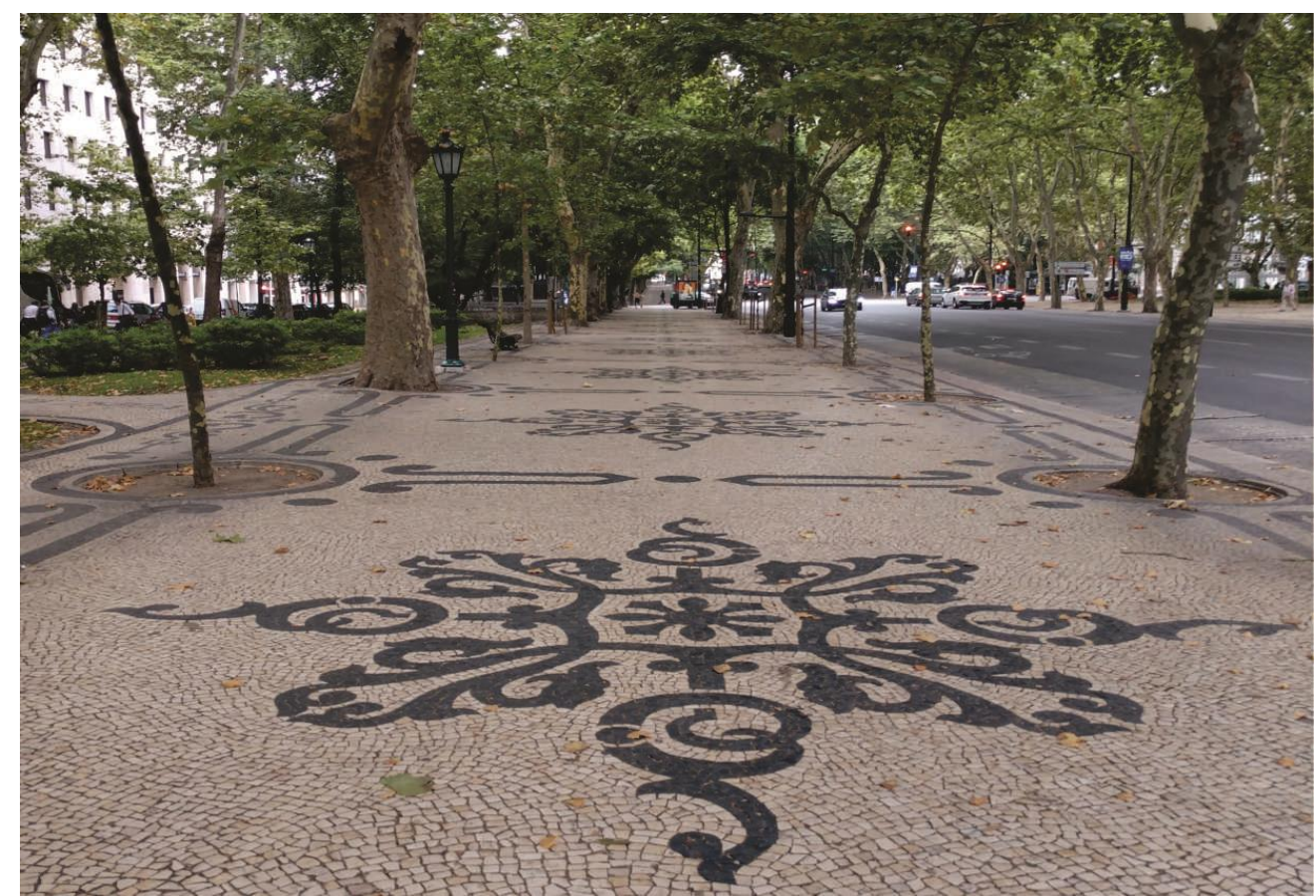

Fig. 4 - Passeio Público integrado à Avenida da Liberdade em Lisboa/Portugal. Fonte: Acervo pessoal do autor (2019). 
Ainda que relembrados, sobretudo, pelas grandes obras de intervenção urbana que os geraram no século XIX e por seus célebres cronistas (Baudelaire, 1985; Benjamin, 2005; Pessoa, 2016; Rio, 2013), os parques públicos urbanos têm uma história um pouco anterior e relacionada à de outras categorias espaciais. Conforme tão bem sintetizado por Segawa (1996, p. 31): “a praça é um espaço ancestral que se confunde com a própria origem do conceito ocidental de urbano. O mesmo não se pode afirmar do jardim ou parque públicos, criações efetivamente materializadas - enquanto espaços públicos - a partir do século XVII". E assim como a característica espacialidade aberta das praças, muitos jardins, pequenos ou monumentais, também se estabeleceram, ainda na Antiguidade, a partir de áreas igualmente abertas mas, por sua vez, elaboradas para um contato com a natureza, geralmente, privativo e, sob uma forte vinculação simbólica em relação ao sagrado. Jardins árabe, oriental, monástico, francês, inglês e moderno consistem em algumas das mais célebres tipologias ou matrizes de manipulação da natureza para a configuração de ambiências abertas, como elencadas por Fariello (2008), ora complementando uma grande edificação ora englobando edificações em sua extensão territorial (Fig. 4).

Caminhando para um maior conhecimento sobre os parques a partir do contexto industrial em que muitos foram criados, vale salientar que a abertura dos primeiros parques ao grande público, ao ser vinculada como um dos muitos desdobramentos da industrialização sobre a esfera urbana, sublinha apenas um dos tantos aspectos da força do processo industrial (MARCUSE, 1973). Tal processo, conduzido sob uma diretriz de desenvolvimento, sobretudo econômico e, inicialmente, espraiado entre os territórios da cultura ocidental pela mão europeia, perpassou campos a ponto de promover uma reorganização social sem precedentes até então, a partir da exploração de recursos naturais e humanos vinculada a uma técnica de produção contraditória, destruidora na criação de inovadoras obras primas. Nesse contexto de influências tão amplas, engendrado junto à formação de uma sociedade industrial, a esfera espacial, apreendida como um conjunto inseparável de forma e conteúdo (SANTOS, 2008), expressa tais alterações nas destruições, reconfigurações e inovações em sua materialidade e nas inter-relações que a perfazem initerruptamente. 


\subsection{Sob uma forte dimensão heterotópica}

Inicialmente vinculadas a grandes forças de poder, principalmente religioso e monárquico, grandes jardins particulares se tornaram bastante influentes em reconfigurações da esfera urbana quando suas áreas de base natural, marcadas por elementos vegetais e hídricos, passaram a ser vistas como um item importante na composição estrutural das cidades; muitos desses jardins ou parques particulares foram, assim, convertidos em espaços públicos junto à constituição dos Estados Nacionais e aos sucessivos efeitos da industrialização logo percebidos como nocivos ao meio ambiente e estimulantes a um romanceamento da natureza. Essas transformações e outras posteriormente observadas no âmbito dos parques, relacionadas à sua configuração e a seus usos, por um lado, explicitam a assimilação do espaço como um processo resultante de inter-relações, logo, passível a renegociações sucessivas, por outro lado, reverberam momentos da produção do espaço, tal como conceituado por Henri Lefebvre (2013): o espaço concebido, apropriado e vivido. E é justamente essa dimensão heterotópica, comum aos espaços por sua característica adaptabilidade a sobre-escrituras de valores e intenções, a sobreposições de momentos e configurações, uma das dimensões que mais se ressalta no âmbito dessa série de parques engendrados pela abertura de jardins históricos privados ao grande público. Afinal, ainda que mantidos em sua essência paisagística, tais reconfigurações - física, de utilização e associação simbólica - evidenciam a heterotopia já característica dos parques ou jardins, essencialmente orgânicos, condicionados pelo fluxo da corrente biológica que os molda.

E sob esse contexto específico, entre outras referências igualmente representativas, a abertura do célebre Kammergarten e outros jardins do Palácio do Belvedere (Fig. 5), antigo Gartenpalais, concebido ao longo do século XVIII e tornado um dos primeiros museus públicos do mundo, consiste em apenas um dos tantos casos emblemáticos desse contexto. Esse antigo jardim barroco, originalmente o jardim privado do príncipe Eugene, escondido por altos muros recobertos por sebe e composto por pavilhões, fontes e parterres, com a sucessiva abertura ao público dos edifícios do complexo palaciano e de seu jardim principal no mesmo século de sua construção, tornou-se, mais de dois séculos após, um espaço de caráter democrático, que exibe cinema ao ar livre no fim das noites de verão e expõe obras artísticas durante o dia, tal como o jardim principal tornou-se dos mais visitados jardins de Viena, hoje já imbricado à malha urbana da cidade e com acesso gratuito durante o dia. 


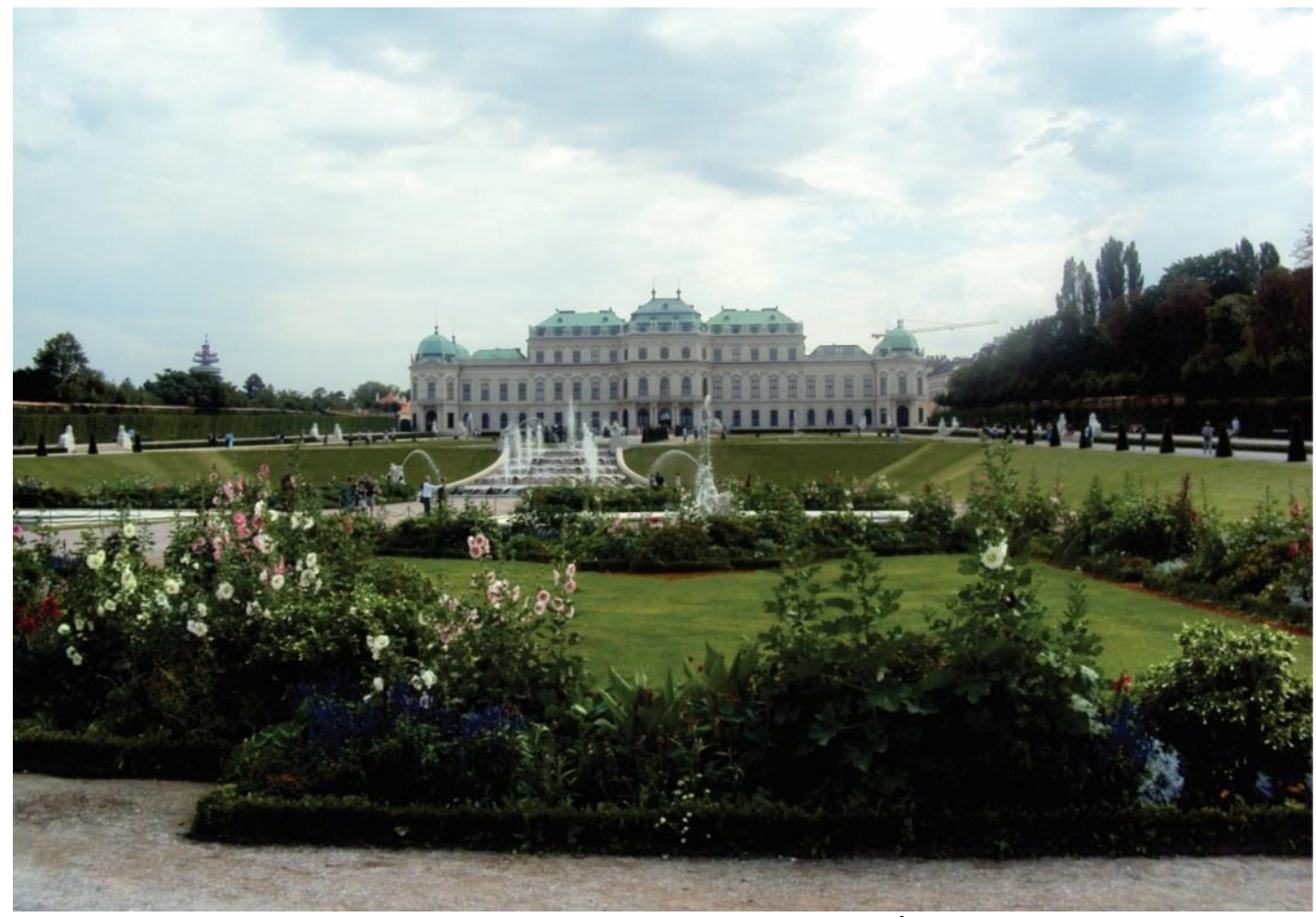

Fig. 5 - Jardins do Belvedere em Viena/Áustria.

Fonte: Acervo pessoal do autor (2012).

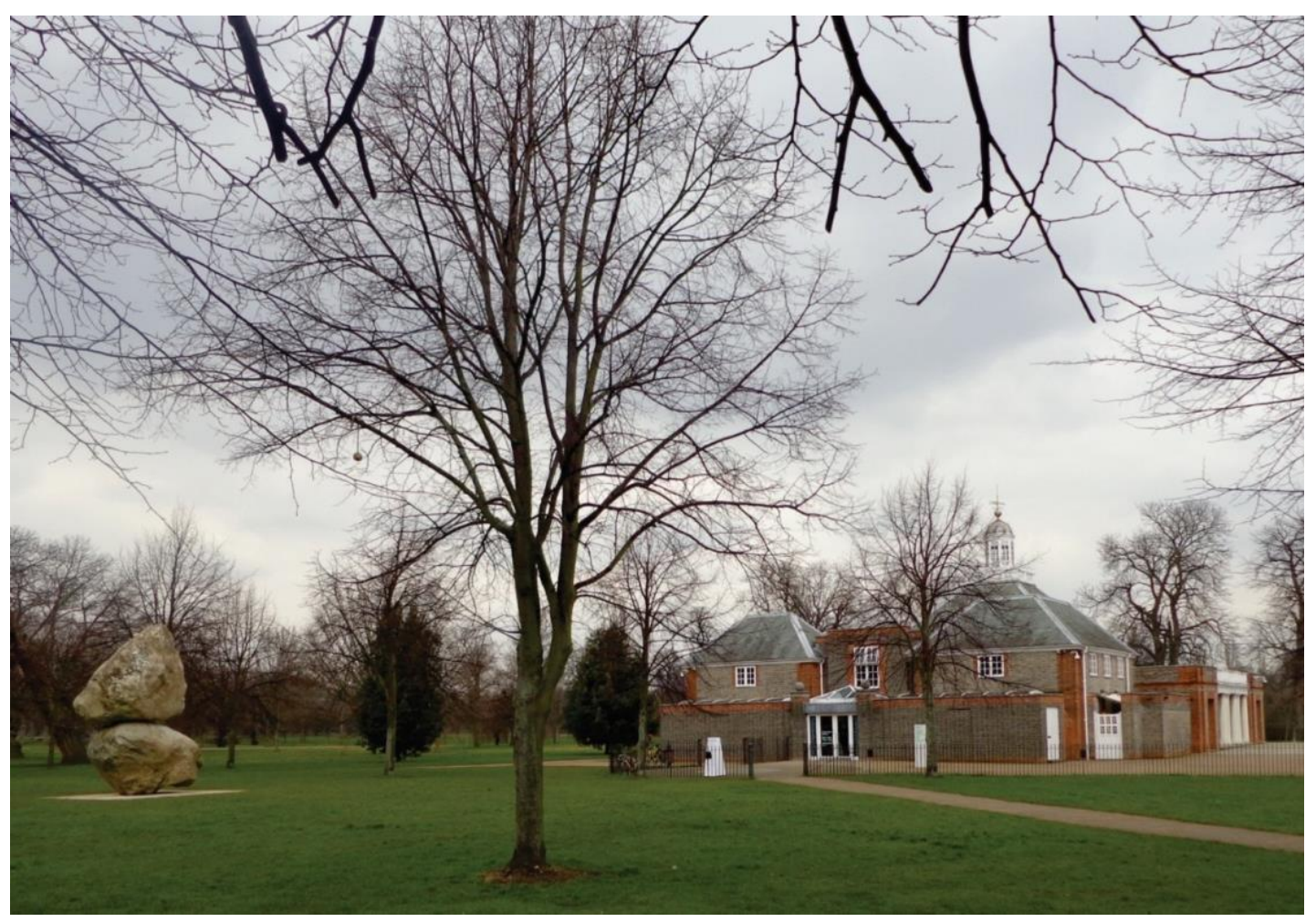

Fig. 6 - Hyde Park em Londres/Inglaterra.

Fonte: Acervo pessoal do autor (2013). 
Um dos parques de maior vitalidade ao longo de sua história e, inclusive, de grande influência mundial, o londrino Hyde Park (Fig. 6), inicialmente vinculado ao contexto aqui enfatizado, no que diz respeito à sua origem como uma reserva de caça real, ativa até o século XVII, quando foi aberto ao público e, em seguida, separado dos jardins do Palácio de Kensington, tem abrigado, sucessivamente, equipamentos e eventos aptos e estimulantes aos valores e interesses (PANZINI, 2013) de momentos posteriores. De facto, poucas décadas após sua abertura, o Hyde Park tornou-se um refúgio temporário para muitos cidadãos de Londres que almejavam escapar da Grande Peste e, já em 1851, foi ali montado, para a primeira Grande Exposição das Obras da Indústria de todas as Nações, o temporário e influente Palácio de Cristal, de Joeph Paxton, cuja arquitetura em ferro revolucionou a história da construção. Já em 1934, próximo ao Lago Serpentine ali criado, o Pavilhão de Chá então inaugurado, convertido no espaço de exposições Serpentine Gallery em 1970 patrocina, desde 2000, um já célebre e esperado pavilhão temporário, o Serpentine Gallery Pavilion, encomendado anualmente a algum arquiteto de destaque internacional para ser instalado no entorno desse prédio histórico durante o verão.

\subsection{Sob uma forte dimensão paisagística}

Tambem entre os séculos XVIII e XIX, a rápida e desordenada ascensão das primeiras cidades da Era Industrial fez com que muitas áreas verdes ou livres fossem rapidamente sobrepostas por construções que adensaram o tecido urbano das cidades. Antes das primeiras propostas urbanísticas para a nova realidade (CHOAY, 2018), tal situação trouxe aos citadinos uma carência de ambiências livres para a realização de atividades diversas, além do problemático convívio com insalubridade e poluição atmosférica, exponenciadas pelas primeiras fábricas. Sob a força dessas premissas em discursos legitimadores de ações voltadas a uma higienização urbana, outras motivações para tais intervenções assim empreendidas tornaram-se mais identificáveis somente com o tempo, como as de controle social e até mesmo de higienização social nas centralidades urbanas: fosse no estímulo a um "ver e ser visto" no footing da burguesia, fosse no lazer ainda mais vigiado da classe trabalhadora - quando não excluída das imediações da nova paisagem urbana renovada. Assim, atrelada às intervenções urbanas da época e, por vezes, convertendo-se em seu 
componente principal, a construção de praças e parques nas áreas centrais de muitas cidades influenciou padrões de sociabilidade orquestrados sublinarmente no espaço público sob a atratividade estética e ambiental desses espaços em sua dimensão mais aparente, sua dimensão paisagística, à época inovadora ou amparada em releituras históricas.

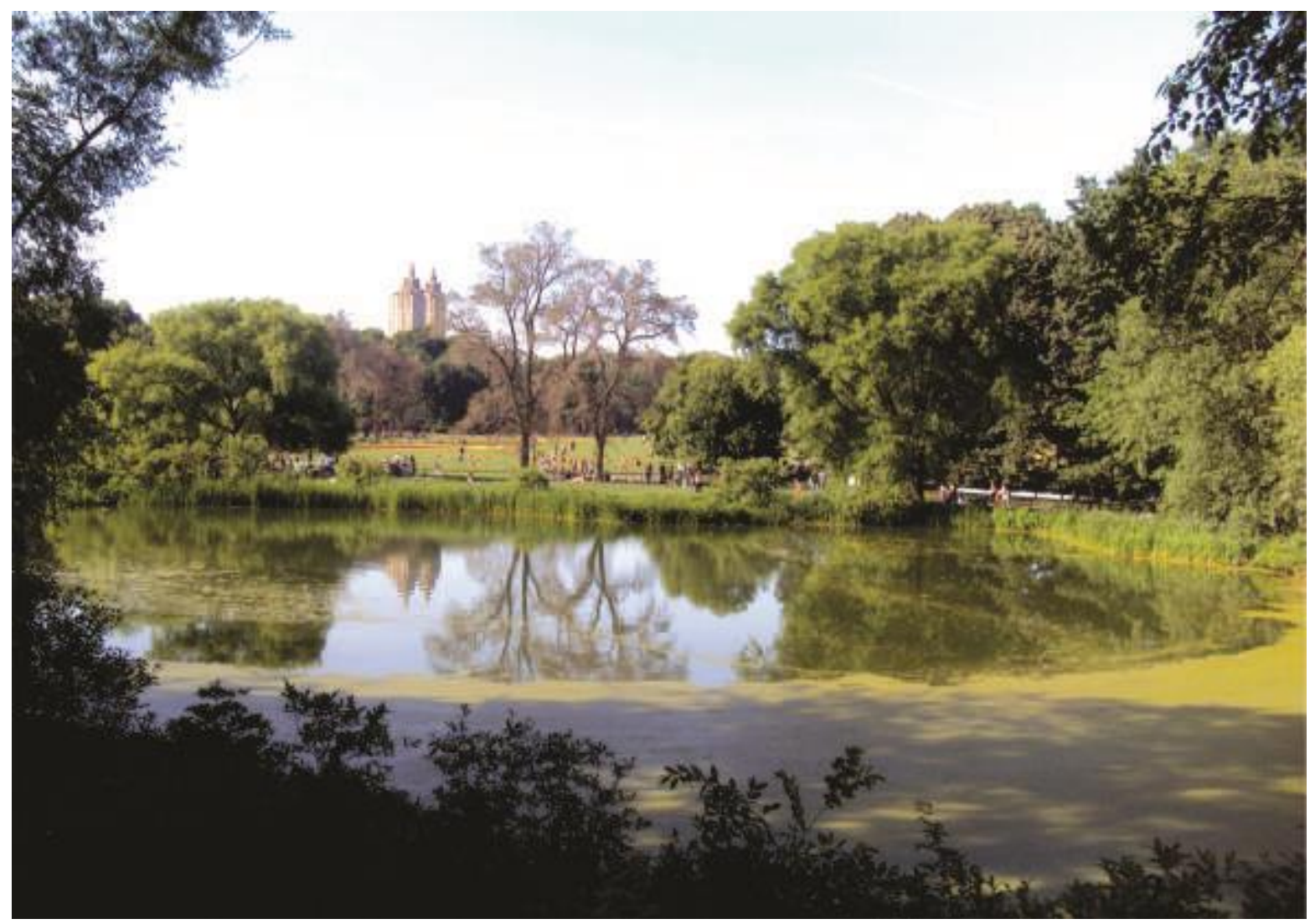

Fig. 7 - Central Park em Nova lorque/EUA.

Fonte: Acervo pessoal do autor (2014).

Vias urbanas largas e arborizadas, como as alamedas, os bulevares, as ramblas, os passeios públicos, assim como os novos ou reconfigurados jardins e praças, cristalizaram-se como respostas espaciais centrais nas estratégias de intervenção urbana adotadas por muitas cidades a partir de experiências influentes como as empreendidas por Georges-Eugène Haussmann, iniciada em 1853 em Paris e, por Ildefons Cerdà, iniciada em 1859 em Barcelona. Assim se difundiu, a partir da Europa, o programa do passeio público ou parque público entre outras designações, construído em vazios urbanos ou em áreas previamente ocupadas, como no caso do Central Park de Nova lorque (Fig. 7), idealizado por Frederick Law Olmsted e Calvert Vaux, também na década de 1850, a partir dessas e outras 
referências europeias, como as inglesas do Hyde Park e do Birkenhead Park. Tempos após sua criação no centro de uma cidade que, à época, quadruplicara sua população e, em uma área até então ocupada por várias comunidades, como a Seneca Village, habitada principalmente por afro-americanos e imigrantes europeus, o Central Park consolidou-se como uma dos projetos de caráter paisagístico mais célebres internacionalmente na reconfiguração urbana de grandes centralidades.

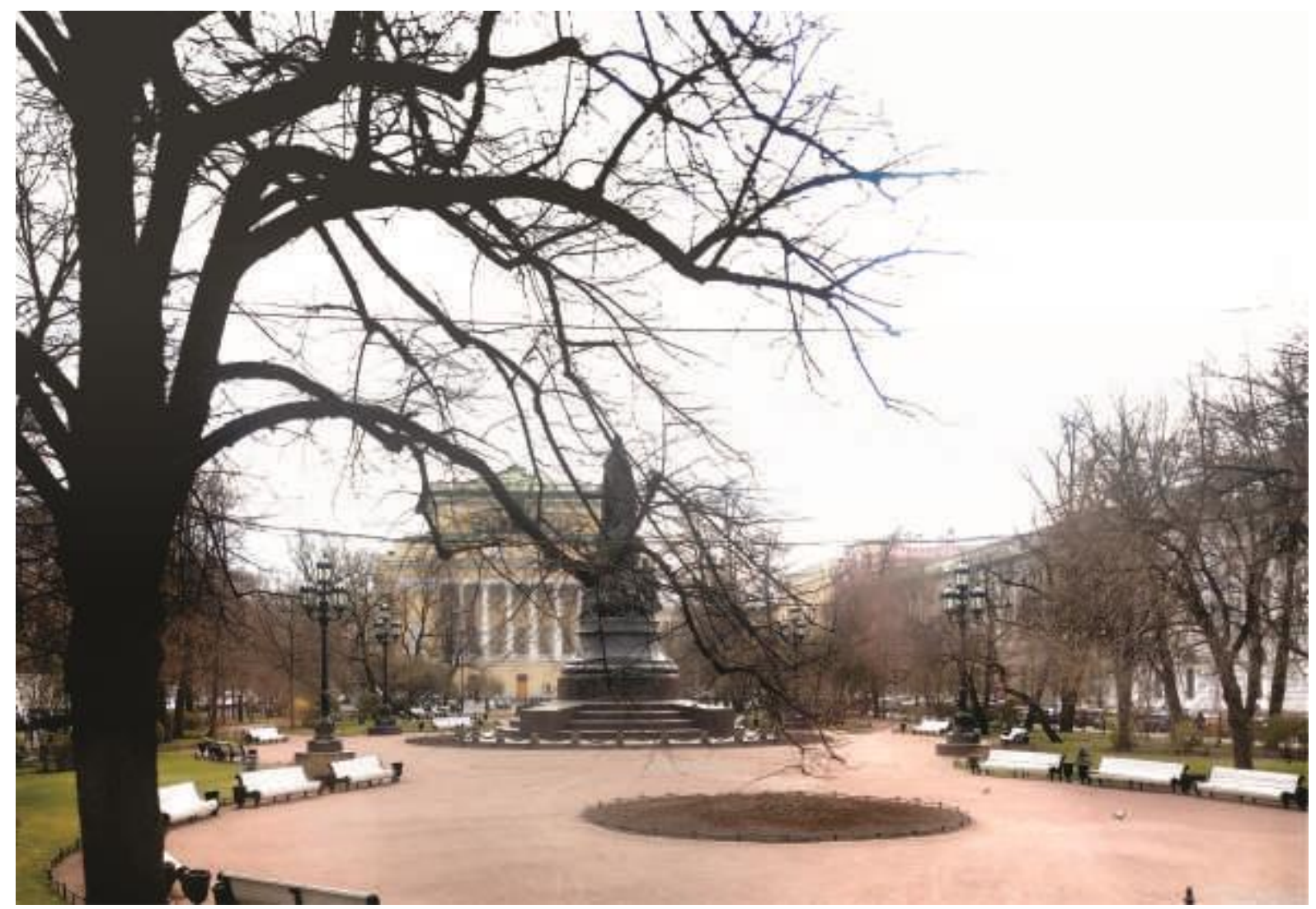

Fig. 8 - Ostrovsky Garden em S. Petersburgo/Rússia.

Fonte: Acervo pessoal do autor (2019).

Uma menção ao caso do complexo arquitetônico e urbano conhecido, entre outras designações, como Ostrovsky Square Garden (Fig. 8), situado na cultuada Avenida Nevsky de São Petersburgo, se mostra bastante pertinente por evidenciar muitas das intenções, características e desdobramentos dessas intervenções urbanas que, durante o século XIX, (re)estruturaram tantas cidades tendo as áreas verdes como apoio ou foco de projeto (FARIELLO, 2018). Implementado a partir de 1816, foi conduzido pelo autor das mais emblemáticas obras do período neoclássico da cidade (TARANOVSKAYA, 1980), como a ala 
componente deste projeto e que hoje o homenageia, a Rua Arquiteto Rossi, reconhecida como um dos grandes momentos do urbanismo em razão da harmonia alcançada em sua composição. Inicialmente nomeado como Alexandrinsky Garden, em referência ao Teatro Alexandrinsky que, desde 1832, centraliza o complexo formado por um sistema de vias e edifícios, como pavilhões, edifícios-galeria, a Biblioteca Nacional, o Palácio Anichkov e seu jardim, outras expressões como Catherine Garden referenciam o local, desde 1873, quando foi ali adicionado um monumento à Catarina II, além do nome atual, adotado em 1923, numa homenagem da Leningrado socialista ao dramaturgo russo Aleksandr Ostrovsky.

\subsection{Sob uma forte dimensão conceitual}

Após as primeiras reformulações urbanas que marcaram o século XIX, várias proposições inovadoras e até mesmo utópicas se somaram às alternativas suscitadas para intervenção ou criação de cidades. A expressão "cidade jardim", entre as mais célebres proposições desse momento, difundiu-se a partir da proposta de uma "cidade-campo" apresentada pelo inglês Ebenezer Howard (2012), em sua publicação de 1898, logo seguida de casos diversos, vinculados a outros enfoques para uma "cidade moderna", mas também associados ao conceito de "cidade jardim" ou "cidade parque" por adotarem, entre suas características próprias, a presença de consideráveis áreas naturais nas centralidades urbanas. A própria Carta de Atenas de 1933, código de posturas influente que sintetizou diversos problemas constatados nas cidades a tal altura, e que auxiliou na difusão das propostas modernistas, ou de uma corrente específica, a do urbanismo funcionalista, reverberou as reivindicações precedentes por atenção à natureza em projetos arquitetônicos e urbanos. No caso dos parques gerados sob tais vínculos, os "parques modernos", ampliados em escala a ponto de permearem todo o tecido urbano da cidade, sua dimensão conceitual, decerto, se sobressai.

No Brasil, antes dos conceitos de cidade jardim e de urbanismo funcionalista, que caracterizaram o ideário moderno, influenciarem a idealização da nova capital federal, Brasília, atuações locais como a da empresa imobiliária inglesa Cia. City concretizaram projetos afins, como o Jardim América, entre 1917 e 1919, a partir do projeto de Parker, logo replicado em outros bairros de São Paulo e demais cidades brasileiras. Também em São Paulo, desde 1954, o Parque Ibirapuera (Fig. 9), então inaugurado, vem se configurando 
como um dos parques urbanos modernos de relevância internacional a partir da associação entre o paisagismo de Otávio Mendes - de Burle Marx em um dos espaços - e os edifícios, elaborados por um grupo liderado por Oscar Niemeyer e unidos por sua generosa marquise; elementos que, juntos, configuram ambiências aptas à contemplação, recreação e cultura, como as já históricas Bienais Internacionais de Arte e Arquitetura de São Paulo, entre outras atividades de ocorrência suscetível em áreas externas e internas do parque.

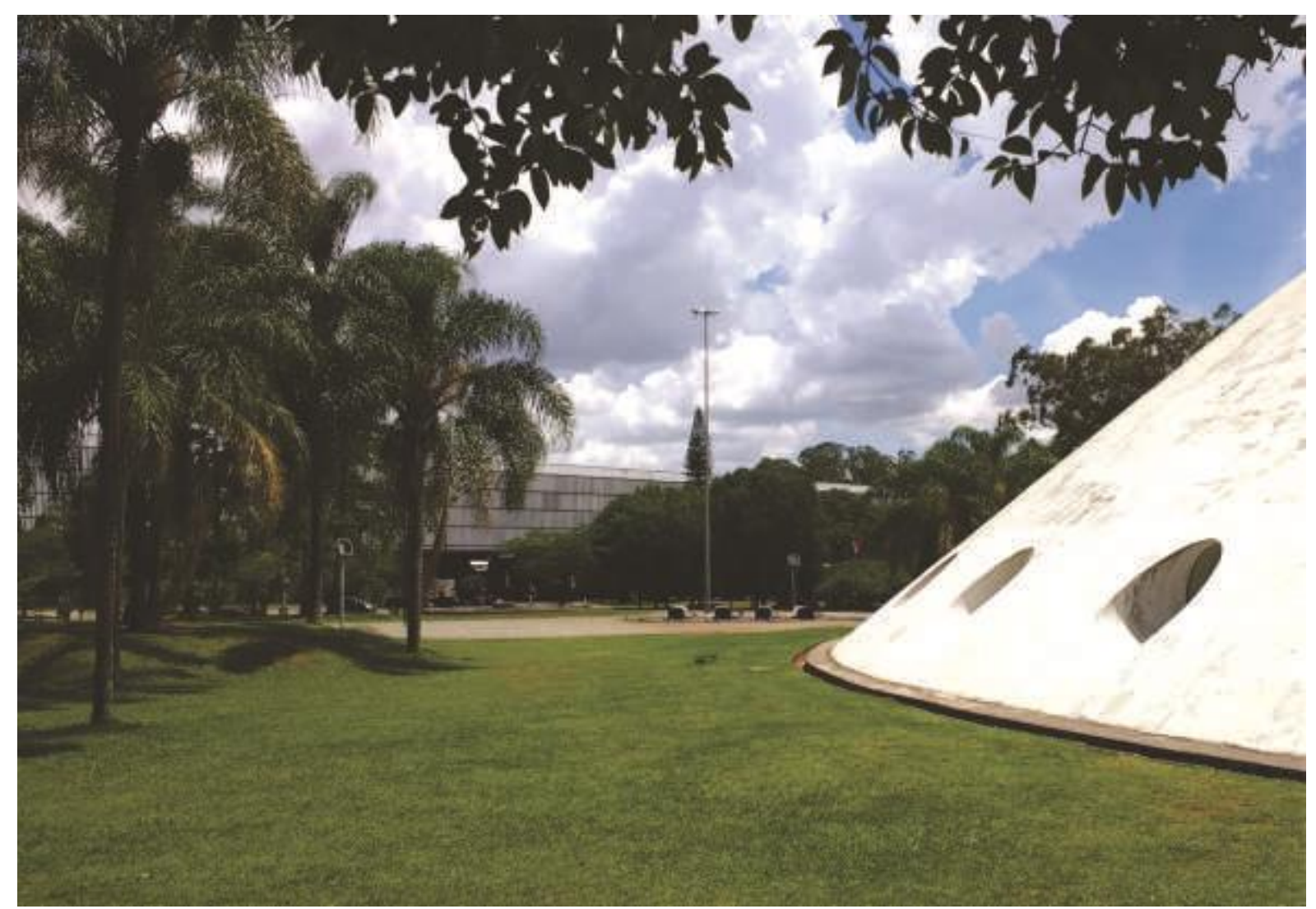

Fig. 9 - Parque Ibirapuera em São Paulo/Brasil.

Fonte: Acervo pessoal do autor (2017).

Sob as linhas propositivas que configuraram o ideário moderno de intervenção sobre as cidades até meados do século $X X$, se fez sempre presente, mesmo que em graus variados, a valorização da categoria espacial representada pelos parques ou jardins, tanto nas centralidades urbanas históricas que então passaram por intervenções quanto nas cidades novas, propostas como resposta às expectativas e problemáticas da época. Vide casos como o de Camberra, na Austrália, Brasília, no Brasil, Islamabad, no Paquistão, ou da cidade indiana de Chandigarh, outro dos paradigmas do urbanismo moderno do século XX. Idealizada para sediar a capital da região norte do país logo após a reconfiguração territorial 
da Índia ao conseguir sua emblemática independência da Inglaterra, o projeto inicial, de 1949, idealizado por Albert Mayer e Matthew Nowicki, alinhado ao conceito de garden city, terminou sob a cartilha modernista difundida pelo nome mais célebre envolto na construção dessa cidade parque (Fig. 10), Le Corbusier, apesar da significativa participação de Pierre Jeanneret, Maxuell Fry e Jane Drew, no desenvolvimento e concretização do projeto. A partir de uma setorização edilícia e viária disposta em uma malha ortogonal, tal tabuleiro foi permeado por áreas naturais, como praças, o Lago Sukhna e o parque linear criado em meio ao arroio que cruza o plano da cidade, de uma extremidades a outra.

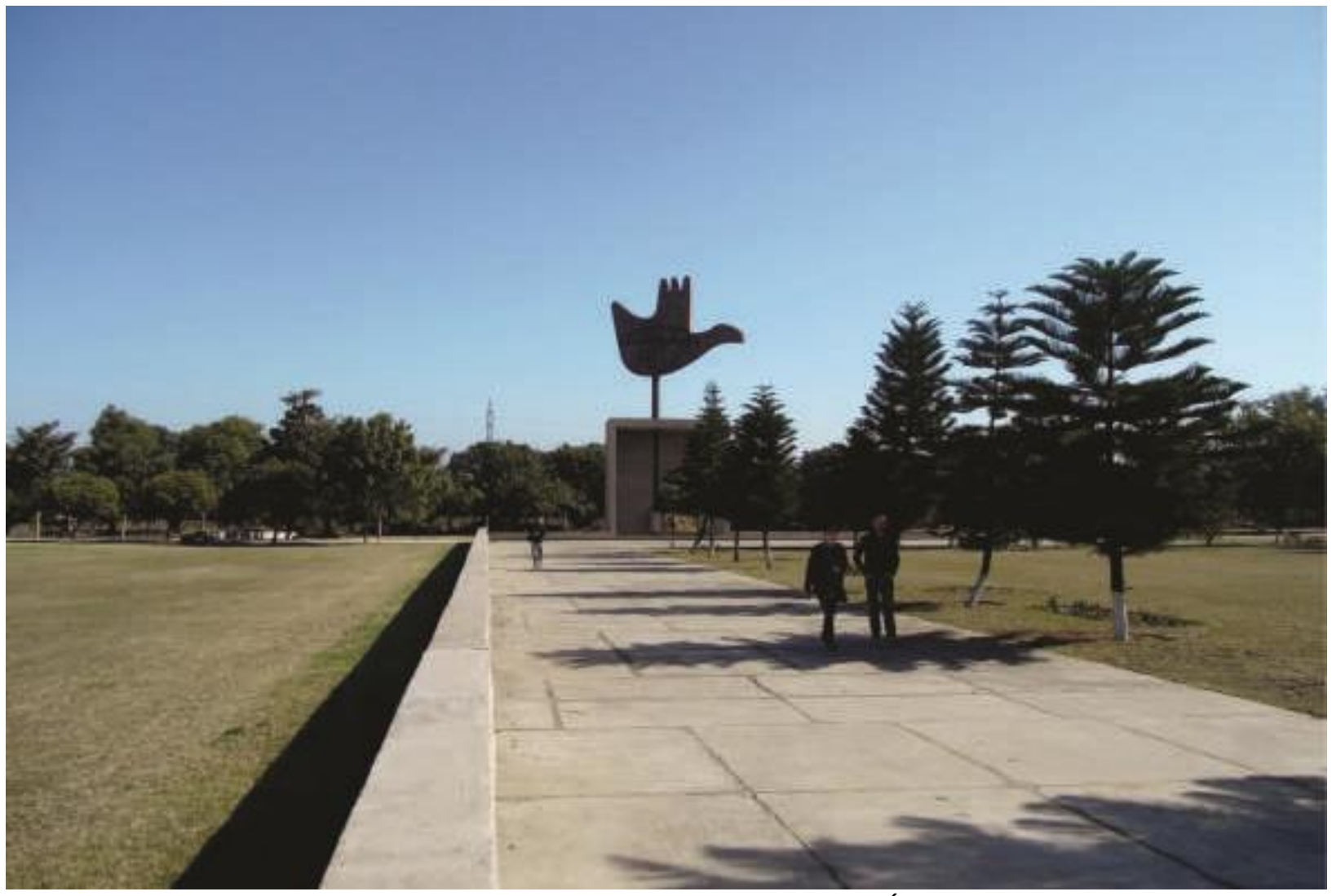

Fig. 10 - Jardins do Capitólio de Chandigarh/Índia.

Fonte: Acervo pessoal do autor (2019). 


\section{Parques públicos urbanos surgidos no contexto pós-industrial}

Para quem quer ver, tudo é arte. A natureza, a cidade, o homem, a paisagem (CLÉMENT, 1997, p. 11).

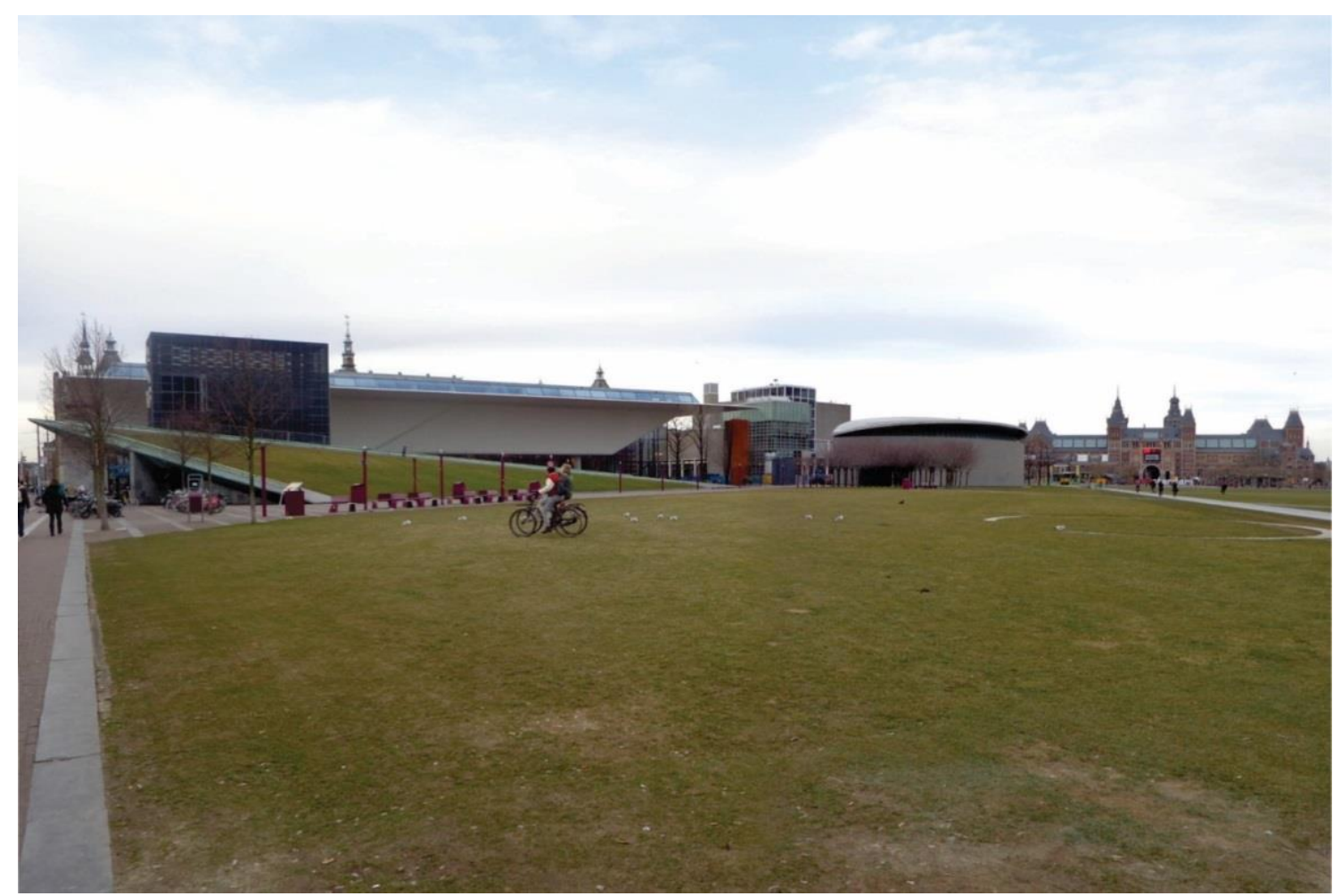

Fig. 11 - Museumpromenade em Amsterdã/Holanda.

Fonte: Acervo pessoal do autor (2013).

Considerando o espaço como um processo, produzido por inter-relações e, logo, aberto, suscetível a alterações, os casos anteriormente abordados sob seu vínculo a um contexto industrial e, evidentemente, ressemantizados por necessidades ou reivindicações trazidas com o tempo, explicitam hoje, em variados graus, questões atuais que os tornam expressões espaciais também contemporâneas. Todavia, emergem sobre a malha urbana das mais variadas cidades parques urbanos novos, criados nas últimas décadas e bastante expressivos de questões contemporâneas já em seu surgimento. Ainda que considerados pelas mesmas dimensões acima evidenciadas na abordagem dos parques surgidos no contexto industrial, os parques urbanos surgidos no contexto pós-industrial, se vinculam a esse contexto posterior sob vários aspectos. São parques surgidos como reflexões espaciais (críticas ou afetivas) a momentos históricos anteriores ou surgidos como espelhamentos espaciais de características da atualidade ou, ainda, surgidos como reconfigurações de 
espaços construídos e já ociosos. Sobre essa última característica de alguns parques ou outros espaços contemporâneos, surgidos pela revitalização de espaços remanescentes, de base residual, se faz pertinente salientar o quanto se vinculam, justamente, a antigos espaços industriais.

E entre as muitas transformações em ocorrência por todo o globo, também têm sido várias as interpretações e conceituações sobre a contemporaneidade; um contexto "pósindustrial" (BELL, 1977) se o considerarmos por se caracterizar como um momento marcado não mais pela produção industrial e sim pelos serviços, pelas tecnologias de informação e comunicação, pela circulação do conhecimento capitalizado. Conhecimento esse, como o que se encontra envolto, por exemplo, na assimilação, no consumo e na divulgação de culturas distintas, gerando como seus espaços mais emblemáticos os chamados "parques arquitetônicos". Difundidos desde os anos 1980, são parques gerados, ora sob a valorização ou consumação da cultura pela associação entre espaços novos e pré-existentes em circuitos culturais urbanos (Fig. 11), ora como demarcação explícita da atual força da tecnologia e do próprio capital financeiro nos novos parques tecnológicos e nos onerosos "centros de conectividade internacional" (MASSEY, 2008). O termo pós-industrial, ainda que pouco usado no campo da arquitetura e do urbanismo (RAJA, 1993), permite, sob tais associações de seu significado, operacionalizar reflexões sobre a esfera urbana recente e seus parques surgidos como portadores de significados crescentemente diferenciados.

\subsection{Sob uma forte dimensão conceitual}

Precoce foi a percepção de Robert Smithson (1967) sobre a industrialização como um momento já transposto, seu texto Monuments of Passaic, escrito após sua deambulação e registro fotográfico junto às ruínas industriais de sua cidade natal, as difundiu sob uma dialética entre o efêmero e o legado. Ao se referir à contemporaneidade como uma pósmodernidade, marcada pela saudade e nostalgia que têm levado a mesclas aleatórias de tudo um pouco, Doreen Massey (2008, p. 166) ressalta o quanto “(...) isto é tomado como uma forma de rebelião contra o excesso da racionalização e o domínio de estruturas fechadas. Uma reação contra os excessos e a parcialidade do moderno". De facto, como clara contraposição à limitação dos propósitos ordenadores característicos da experiência 
moderna, desde os anos 1950 emergem reflexões, críticas e proposições reivindicando mudanças. Evidencia-se, assim, em muitos parques públicos contemporâneos, sua carga conceitual, não por acaso, vinculada à valorização de respostas espaciais bem mais abertas que as precedentes, da projetação ao uso: atentas à multiplicidade heterogênea já presente no espaço urbano, atentas à indeterminação de seu devir como algo que lhe é imanente.

Inaugurado em 1988, o pequeno Jardim de Esculturas do Centro Canadense de Arquitetura (CCA), ou CCA Garden (Fig. 12), consiste em uma exímia alegoria desse momento e de uma ênfase conceitual. Situado em Montreal, entre um boulevar e uma via expressa, na Esplanada Ernest-Cormier pertencente ao CCA e dentro de um cercamento que simula a base da Shaughessy House - edificação histórica que abriga o instituto - esse parque urbano foi elaborado de modo crítico e irreverente por Melvin Charney com pouquíssimos elementos e amplos significados. Na fronteira entre arquitetura, escultura e paisagem, suas peças, que compõem um pequeno mas autêntico jardim público, narram metaforicamente a história local a partir de referências à história geral da arquitetura e, também, das obras arquitetônicas remanescentes e já demolidas, principalmente, no bairro industrial de SaintHenri, para o qual se abrem seus pontos focais. Promovendo uma série de episódios narrativos por meio de históricos elementos estruturais do paisagismo e dos parques como esplanada, prado, pomar, alameda e arcada - sua estratégia discursiva culmina em uma programada disposição de "colunas alegóricas" compostas de pedestais encimados por elementos cuja dualidade - um obelisco-chaminé, um templo-silo, etc. - reverbera a história geral da arquitetura contraposta ao legado arquitetônico da cidade.

A ênfase conceitual e o processo de projetação e utilização proposto na concepção do Parc de la Villette (Fig. 13), concebido por Bernard Tschumi, entre 1983 e 1987, fazem dele um marco na renovação dessa categoria espacial. Vinculado a referências da vertente filosófica contemporânea do desconstrutivismo - difundida por Jacques Derrida, que quase participou da elaboração de um dos jardins do parque com Peter Eisenman - tal parque transpôs ao campo da arquitetura e do paisagismo reflexões inovadoras como as de outras linhas de pensamento e linguagem emergentes, desde meados do século $X X$, em busca de respostas espaciais para problemas surgidos ou agravados no contexto industrial, espacializado sob os parâmetros modernistas de funcionalidade. Mantendo um dos edifícios do local, o parque foi composto por três camadas de projetação: a dos volumes naturais e edilícios, a dos eixos 
lineares de circulação e a camada dos elementos pontuais que entremeiam os demais como marcos. Esses marcos, pavilhões ou folies, criados para atender a funções específicas ou sem uma utilização predefinida, engendraram volumes ora originais ora referentes a obras célebres da arquitetura (como a Torre de Tatlin, um dos ícones das promessas do progresso industrial) e da arte (como os fragmentos de Tinguely, pioneiras representações a partir dos cacos da modernidade industrial). Tschumi (2000, p. 173) assim ressaltou as potencialidades conceituais e carências espaciais de seus projetos mais investigativos, como La Villette: "[...] se eu fosse examinar tanto meu próprio trabalho dessa época quanto o dos meus colegas, diria que ambos foram o resultado de uma crítica sobre arquitetura, da natureza da arquitetura. Ela desmantelou conceitos e tornou-se um notável instrumento conceitual".

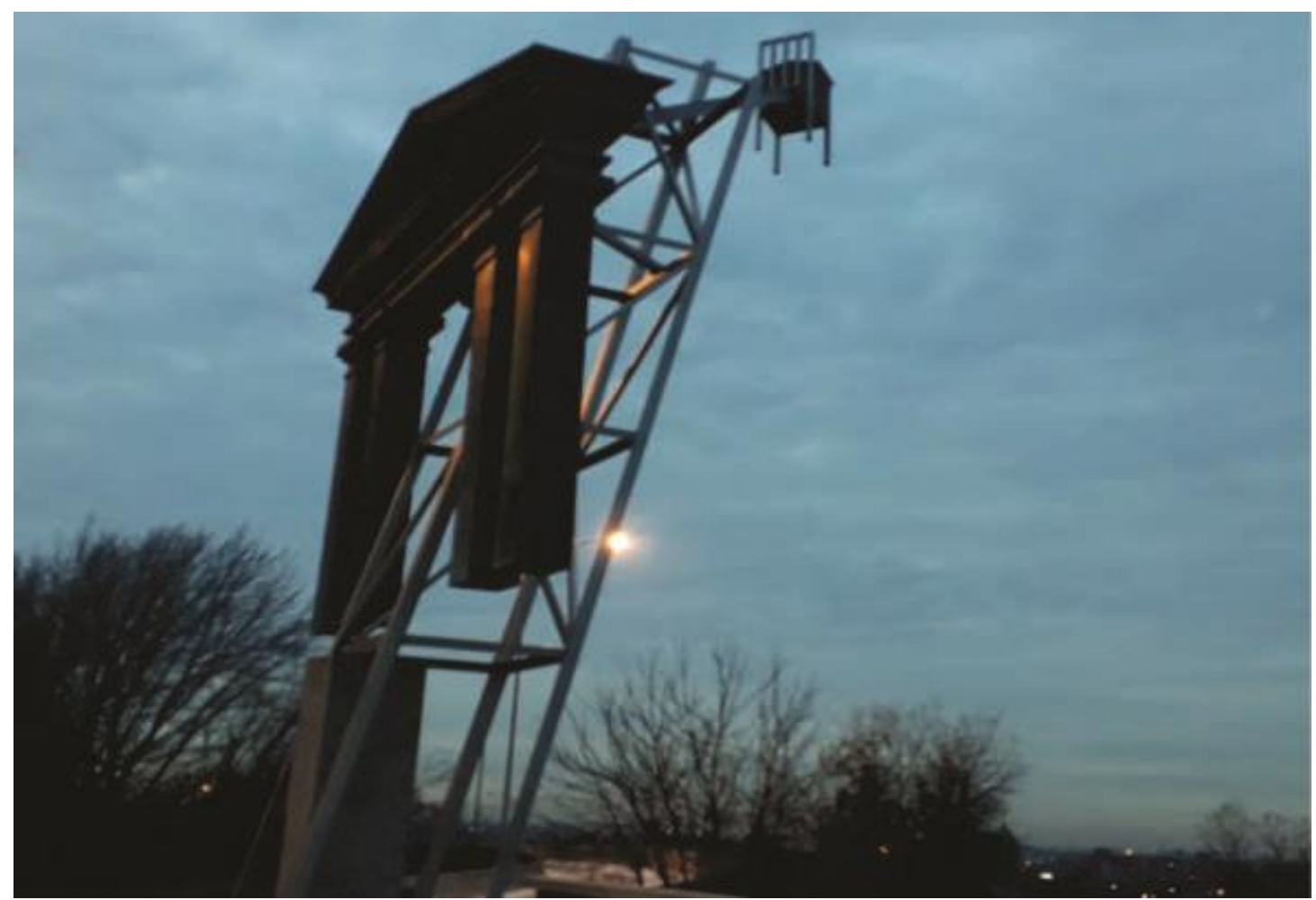

Fig. 12 - CCA Garden em Montreal/Canadá.

Fonte: Acervo pessoal do autor (2018). 


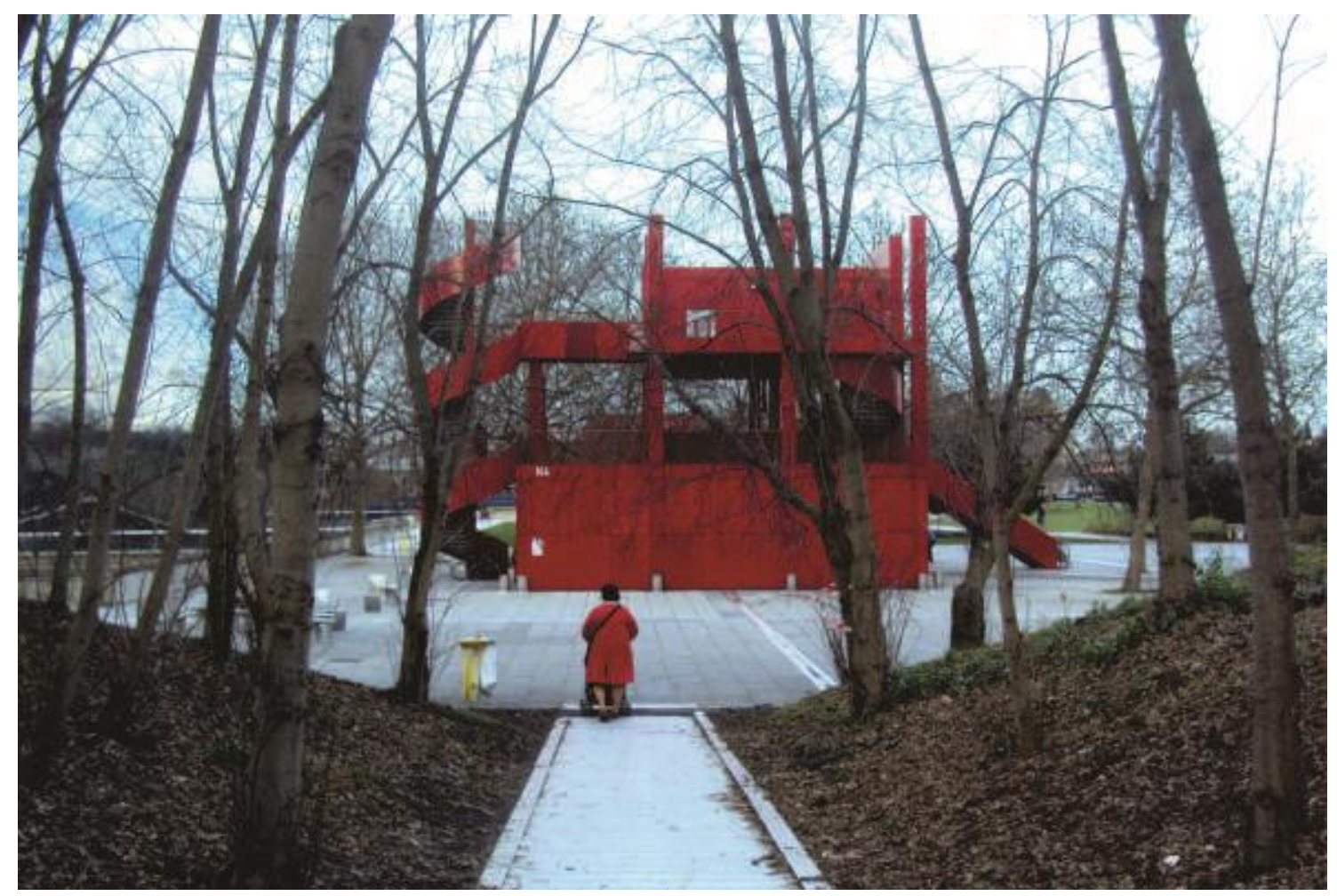

Fig. 13 - Parc de la Villette em Paris/França.

Fonte: Acervo pessoal do autor (2013).

\subsection{Sob uma forte dimensão paisagística}

Na contemporaneidade também são muitos os parques que se notabilizam, evidentemente, por sua dimensão paisagística, característica essencial da categoria espacial representada pelos parques ou jardins públicos. Sobre seus vínculos com o atual contexto pós-industrial, tais casos também se apoiam na valorização da informação, presente tanto em referências culturais quanto em elementos naturais que permeiam sua configuração. Assim como o desenvolvimento das Ciências Sociais tem auxiliado no reconhecimento da diversidade cultural e em sua valorização, a crescente problemática ambiental, exponenciada pelo modo de exploração industrial adotado em relação aos recursos naturais, tem engendrado novas assimilações sobre a natureza e crescentes discursos e ações pautados em sua valorização e em possíveis inovações que, direta ou indiretamente, envolvam, preservem ou promovam essa esfera. Vale enfatizar, contudo, a linha cada vez mais tênue entre reais sensibilizações sobre as esferas da cultura e meio ambiente e sua exploração simbólica como commodities; Gould e Lewis (2017) já cunharam, inclusive, o termo greengentrification, para se referir a processos de especulação vinculados à hipervalorização de espaços urbanos envoltos por 
áreas verdes, tal como já ocorrente pela exploração simbólica de espaços urbanos, geradora do processo, conceituado por Ruth Glass (1964), nos anos 1960, como gentrification.

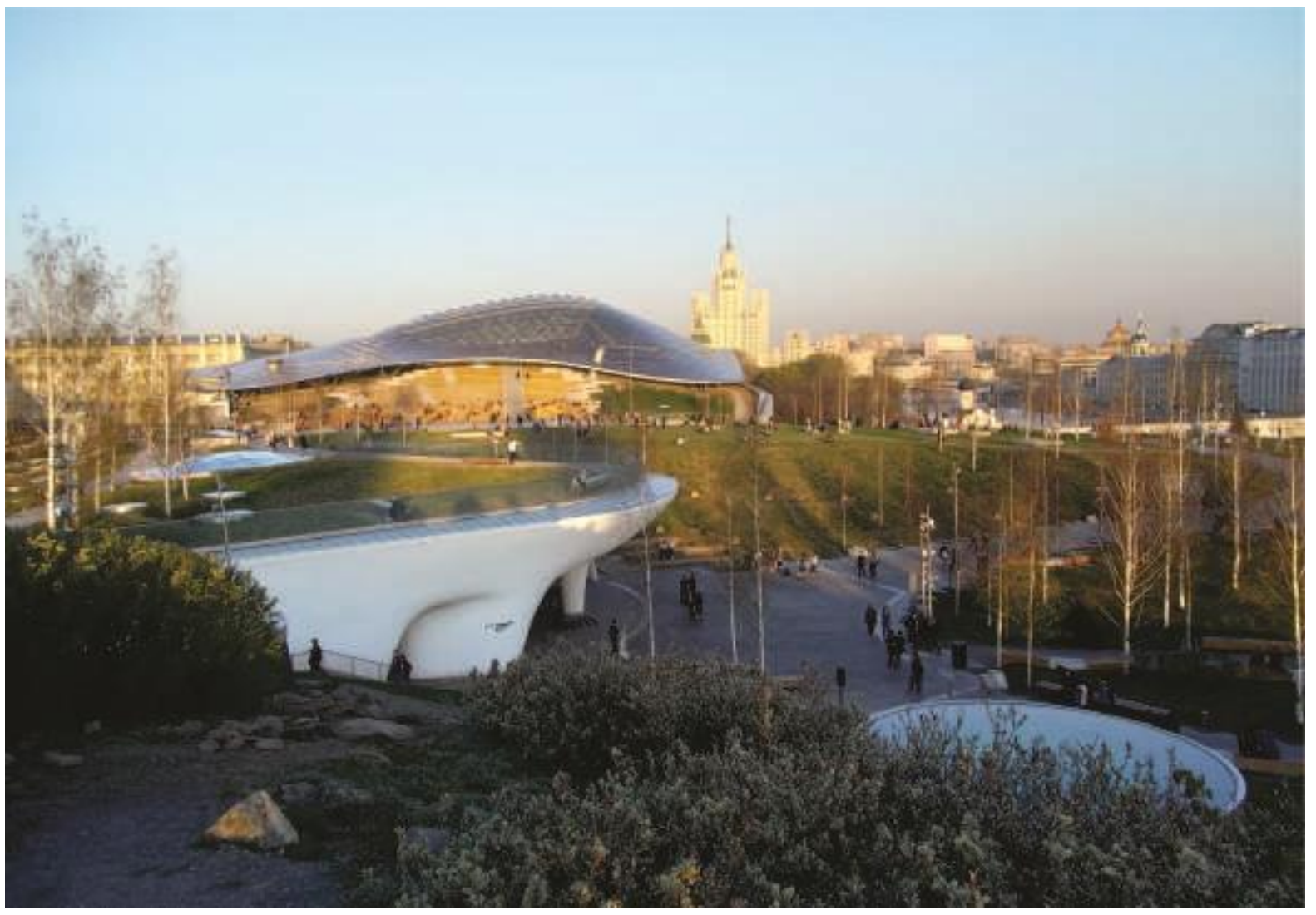

Fig. 14 - Zaryadye Park em Moscou/Rússia.

Fonte: Acervo pessoal do autor (2019).

Esses múltiplos aspectos que agora envolvem a esfera ambiental e ações a ela vinculadas, podem ser exemplificados, de certo modo, pelo Parque Zaryadye (Fig. 14), inaugurado em Moscou, no ano de 2017. Por um lado, o parque experimenta dispositivos paisagísticos inovadores em meio a suas ambiências abertas, ampliadas visualmente pela organicidade de seus edifícios de apoio que, construídos abaixo ou acima do nível do solo e cobertos por vegetação, evidenciam muitas das estratégias de eficiência energética e sustentabilidade hoje valorizadas no campo da arquitetura e urbanismo. Por outro lado, a busca de uma revalorização cultural e econômica do centro histórico da cidade por meio desse parque, que agora o emoldura em alguns pontos, também foi atendida, tanto pela peculiaridade e uso de alguns de seus equipamentos quanto pela organização de uma equipe internacional para a elaboração do conjunto: Diller Scofidio + Renfro, Hargreaves Associates e Citymakers. 


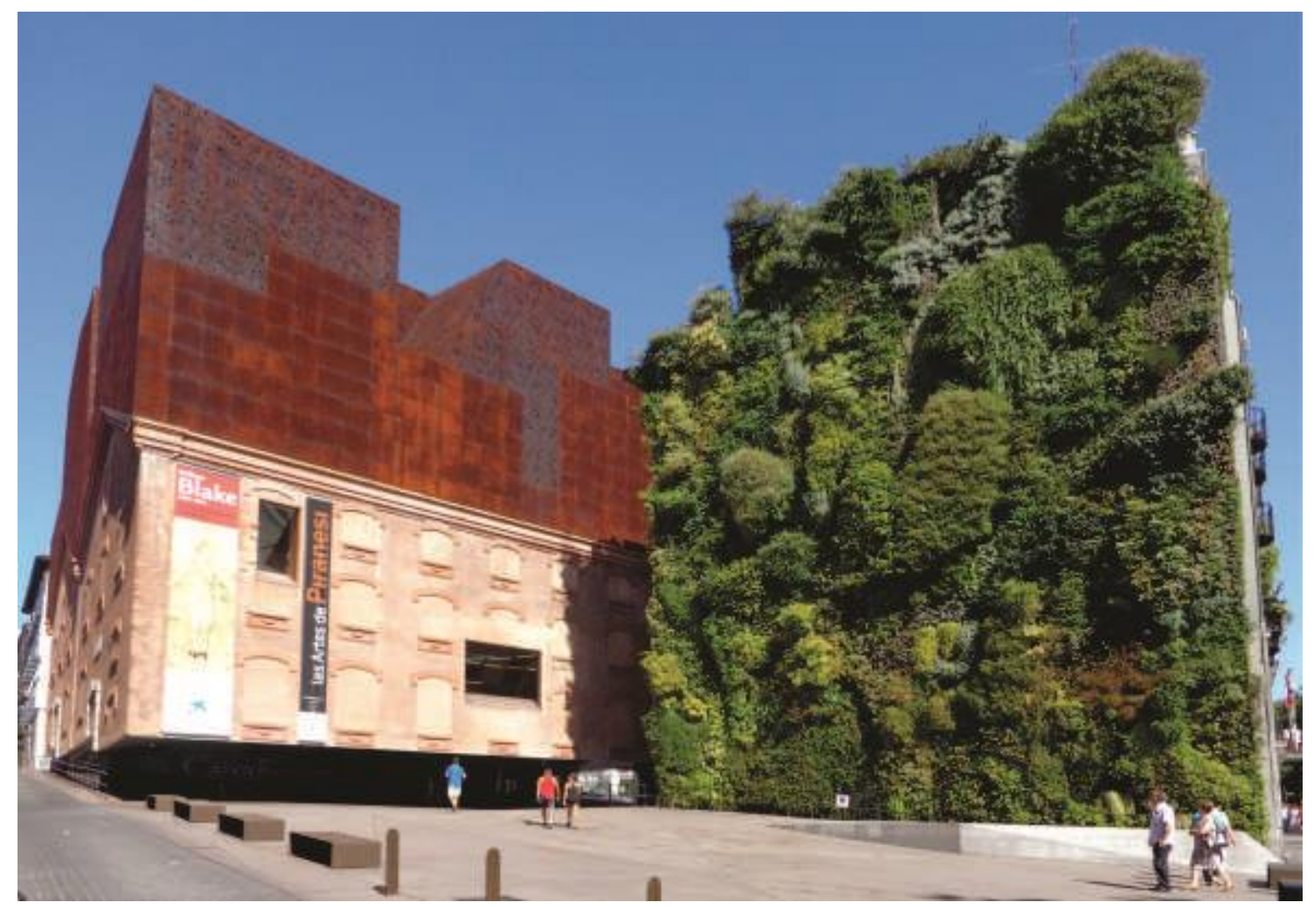

Fig. 15 - Jardim do CaixaForum em Madrid/Espanha.

Fonte: Acervo pessoal do autor (2012).

Outro caso vinculado às mesmas questões pode ser referenciado por um pequeno e inovador jardim espanhol (Fig. 15), ainda que tal obra possa ser vista como um elemento complementar da intervenção promovida pela dupla de arquitetos Herzog \& de Meuron que transformou uma antiga usina hidrelétrica no instituto cultural CaixaForum Madrid - ou como mais um novo atrativo verde do histórico Paseo del Prado e do Jardim Botânico, adjacentes à área onde se situa. Esse inovador "jardim vertical hidropônico", criado pelo botânico e paisagista francês Patrick Blanc, no ano de 2007, autalizou o sistema de paredes verdes idealizado por Stanley Hart White e já difundido por todo o globo. Essa parede verde, muro vegetal ou jardim vertical proposto por Blanck, ainda que ecoe às heras ou outras vegetações historicamente utilizadas na forração de suportes verticais, sofisticou o também estratégico terraço jardim que pautou a arquitetura difundida pela modernidade industrial no que diz respeito a questões como o conforto térmico, segurança e durabilidade, intimamente ligadas a conceitos surgidos no contexto pós-industrial, como os conceitos de 
biofilia, sustentabilidade ou economia circular. De facto, entre o Paseo, a antiga usina, a esplanada que the dá acesso (visual) e a parede medianeira do edifício adjacente, à qual este jardim vertical urbano se conecta por um suporte de afastamento imperceptível, tal quadro vivo, oscilando entre um trabalho de arte urbana e de botânica, composto por cerca de 15.000 plantas, se diversifica em assimilações e significados a partir de sua dimensão paisagística, experienciada visual, olfativa e corporeamente pela névoa emanada nas gotículas de água de sua irrigação (em circuito fechado) experimentada em sua base.

\subsection{Sob uma forte dimensão heterotópica}

Além das peculiaridades expressas sob dimensões conceituais e paisagísticas em vários parques contemporâneos, como os acima abordados, casos ainda mais diretamente relacionados à assimilação do presente como uma fase pós-industrial são representados por uma forte dimensão heterotópica constatada na constituição de muitos deles. São parques elaborados a partir da revitalização de espaços pré-existentes, em boa parte dos casos, remanescentes do desenvolvimento industrial e em estado de abandono ou julgados carentes de intervenção para fins diversos. Ainda que nos deparemos com a desvalorização de culturas diversas, assim como, com percepções sobre a natureza vinculadas à sua histórica desvalorização em relação a um conceito de desenvolvimento e progresso construído sob uma forte base tecnicista (MOORE, 2014), as crescentes demandas pela preservação de referências culturais e ambientais vêm gerando e difundindo essa significativa vertente de projetação, contextualista, simbiótica, sinergética. Tais ações, agora já se vinculando, também elas, a interesses monetários e/ou simbólicos, tiveram suas primeiras ou mais emblemáticas ocorrências nos anos 1970, quando a modernidade industrial passou a ser assimilada por muitos como mais um momento ou fase histórica transposta - após produzir seus diversos legados a gerações posteriores, vale não esquecer, como os de caráter tecnológico e informativo, que hoje nos movem. E, mais recentemente, quando crises globais como a econômica, ambiental e sanitária levam a (ou forçam) um repensar sobre os mais variados temas e ações, ampliam-se as potencialidades e legitimações para a crescente aplicabilidade de propostas vinculadas a tal vertente. 


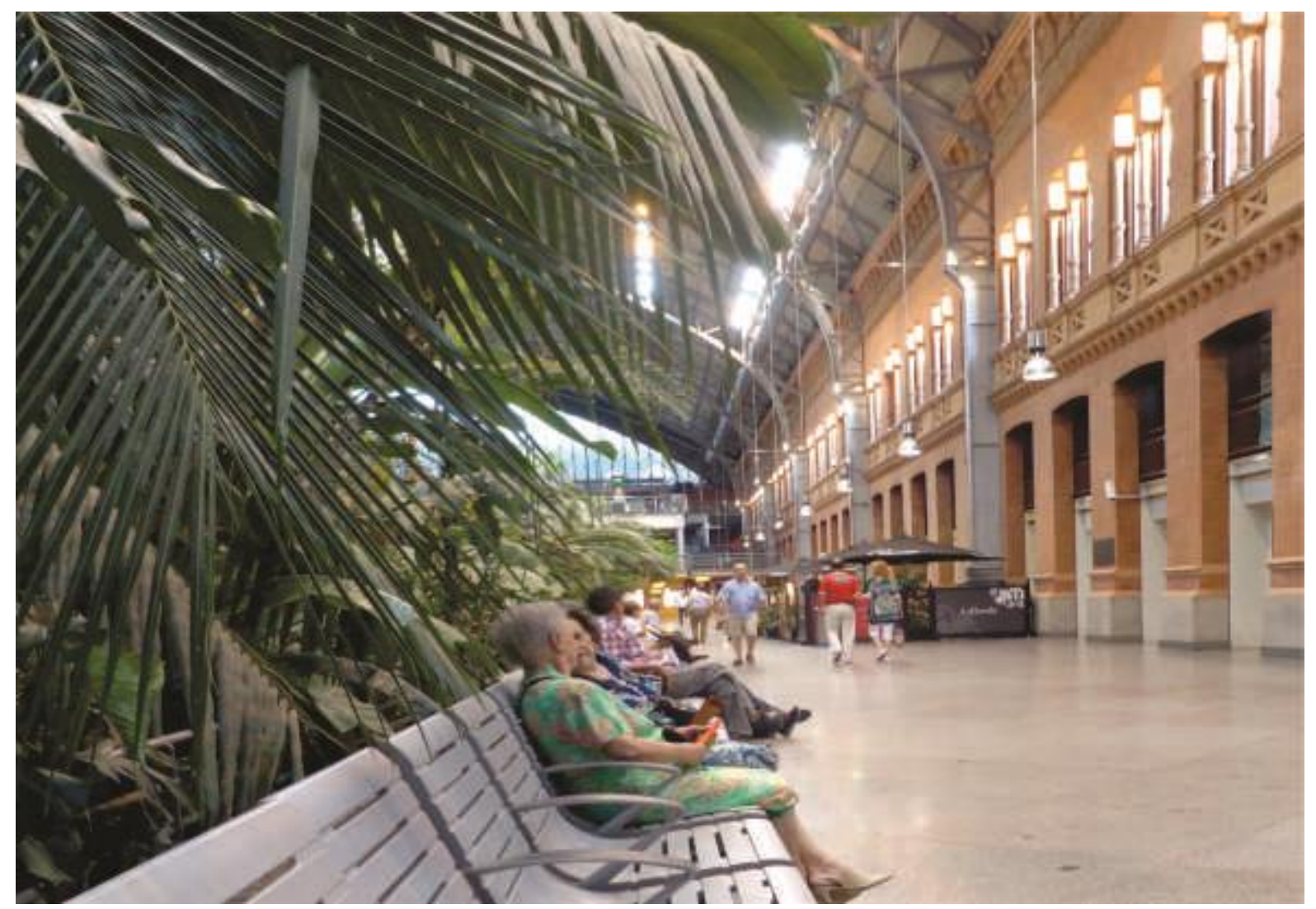

Fig. 16 - Jardim de Atocha em Madrid/Espanha

Fonte: Acervo pessoal do autor (2019).

Sob essa modalidade de criação ou reconfiguração espacial específica, sejam conservadas por sua oficialização como patrimônio cultural ou ambiental, sejam conservadas pela economia de capital e de recursos materiais que tendem a permitir em relação a novas infraestruturas e construções, várias edificações históricas vêm passando por ações de revitalização, restauro, ampliação, retrofit, repurpose, entre outras tantas designações criadas, sucessivamente, para ressaltar a especificidade do processo de intervenção sobre elas adotado. A histórica Estação Ferroviária de Atocha (Fig. 16), inaugurada em Madrid, na segunda metade do século XIX, teve como uma das maiores peculiaridades de seu projeto de revitalização, desenvolvido por Rafael Moneo, em 1992, justamente, um imenso jardim interno. Tal jardim urbano consiste em uma ambiência que, como o tempo, mais que um agradável espaço de espera para viajantes, tornou-se um espaço de convívio entre moradores do bairro e demais cidadãos, estimulando ali, inclusive, a soltura de pequenos animais silvestres pela população - e, tudo isso, em um dos programas arquitetônicos mais vinculados à industrialização e às suas consequências danosas ao meio ambiente, como o programa ferroviário, que revolucionou os meios de transporte de produtos e pessoas. 


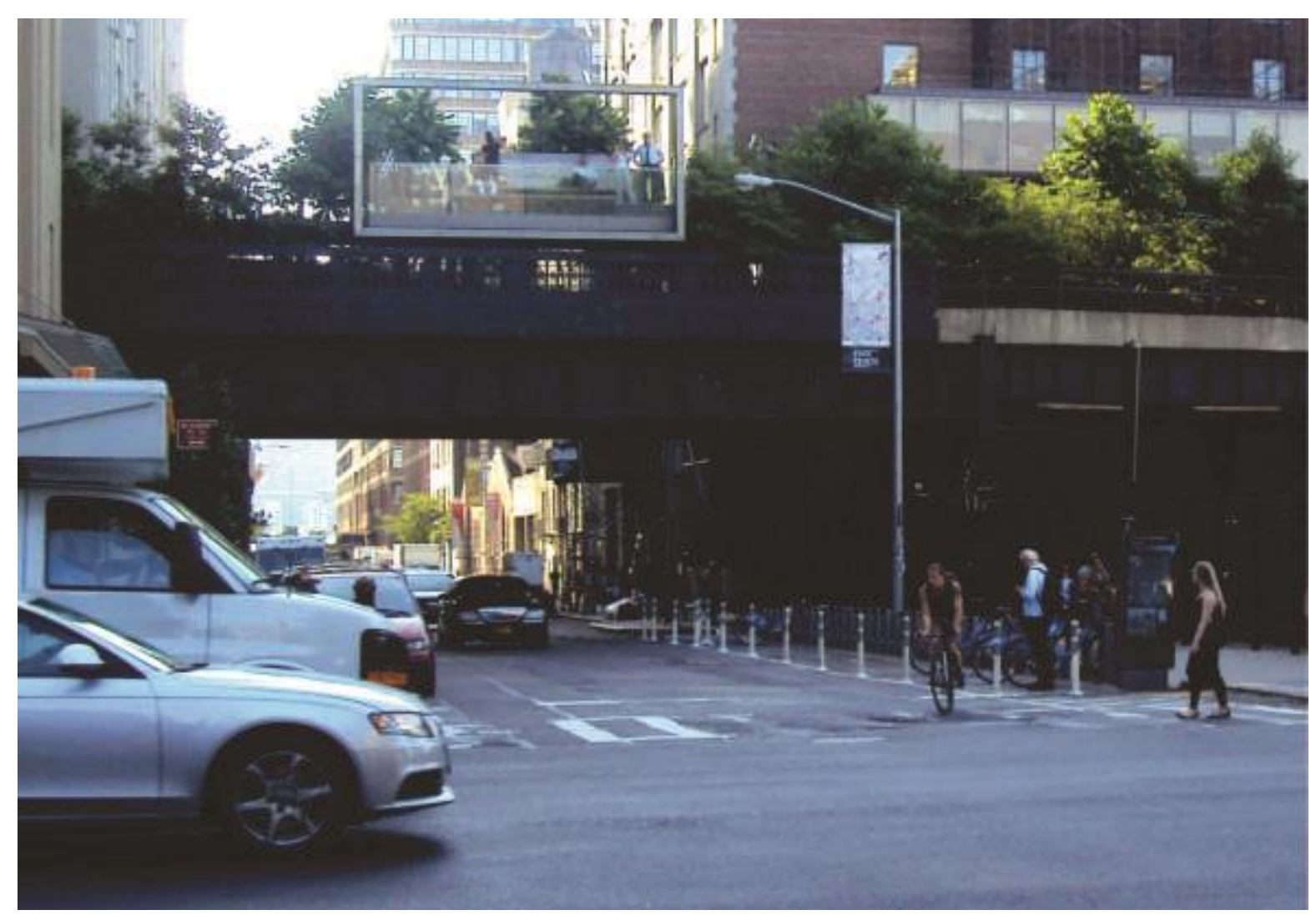

Fig. 17 - High Line Park em Nova lorque/EUA.

Fonte: Acervo pessoal do autor (2014).

Após o abandono do elevado High Line, em Nova lorque, seu segmento que permaneceu como fragmento só não foi demolido em 1999 porque a mobilização local, criadora da associação Amigos do High Line, conseguiu garantias da Prefeitura para a conversão do equipamento num parque suspenso, assim inaugurado, em 2009, à maneira do Promenad Plantée de Paris. Tal como seu potencial econômico e informativo auxiliou em sua reconfiguração, é coerente considerar que também a beleza melancólica e rebelde (JODIDIO, 2006) desta via abandonada tenha estimulado sua transformação, de uma antiga infraestrutura de transporte industrial a um espaço bucólico pós-industrial, bem vinculado às reivindicações contemporâneas no âmbito da cidade. Elaborado pela firma de paisagismo Field Operations e pelo escritório de arquitetura Diller Scofidio + Renfro, o High Line Park (Fig. 17) exibe, de modo significativo, um diálogo entre seu paisagismo e o desenho urbano preexistente permeando questões político-econômicas e simbólico-afetivas. Concebido com várias ambiências que de sua altura elevada nos permitem enquadrar a cidade, já é agora, 
também o próprio parque, enquadrado por edifícios revitalizados e novos a partir de então construídos ao longo de sua extensão, ampliada para abrigar atividades diversas.

\section{Parques públicos urbanos entre paradigmas e singularidades}

A cidade é sempre o homem do primeiro jardim. Tem a fé, tem a paciência, tem o amor, mas não há meio de achar um jardim em si mesma, e vai tecendo o século com outros. Creio que fiz um verso. E vai tecendo o século com outros. (ASSIS, 1996, p. 12).

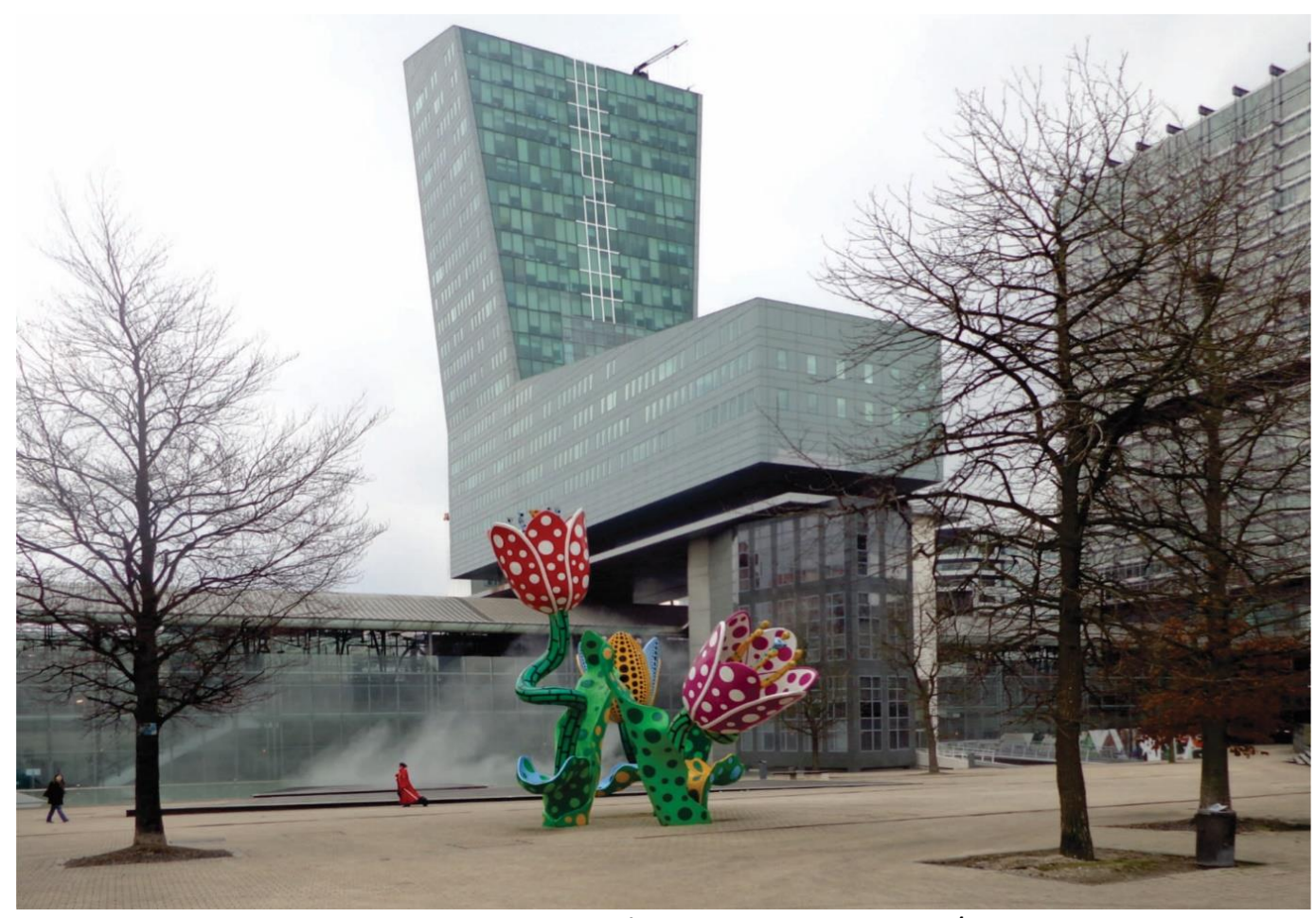

Fig. 18 - Parque Arquitetônico Euralille em Lille/França.

Fonte: Acervo pessoal do autor (2013).

A dinâmica espacial, aqui enfatizada pela abordagem de dois abrangentes contextos históricos, nos permite perceber o quanto a cena contemporânea é marcada por suas especificidades que, como em outros momentos, se vincula a espacialidades novas ou transfiguradas. Como visto, se a atual circulação capitalizada de informações, que se localiza espacialmente apenas em alguns centros de conectividade global, verdadeiras ilhas financeiras materializadas nos impactantes parques arquitetônicos (Fig. 18) que já se tornaram um ideal almejado na desenfreada busca por revigoramento econômico de gestões públicas por todo o mundo, os efeitos crescentes das crises econômica, ambiental e sanitária, já percebidas em escala global, reforçam a importância a ser dada hoje a categorias ou sistemas espaciais como o aqui abordado, o dos parques urbanos - suscetível a tantas outras denominações diante de suas peculiaridades que, somadas a intenções, 
expectativas e transformações sucessivas, os perfazem como equipamentos urbanos de significados que, como visto, transcendem sua dimensão material. De facto, as transformações a que estão sempre sujeitos os parques públicos, conforme explicitadas nessa abordagem, tendem a expressar transformações ocorrentes sob esferas ainda mais amplas, como a que se relaciona à configuração da tecitura geral das cidades (Fig. 19).

No que se refere a essas correlações abrangentes, passíveis de consideração entre os parques públicos urbanos representativos dos contextos industrial e pós-industrial aqui abordados, tais correlações se revelaram, entre paradigmas e singularidades, no exercício comparativo aqui delineado e, não somente suas dimensões conceitual, paisagística e heterotópica aqui evidenciadas formalmente na estruturação da abordagem por sua notória relevância. Decerto, ao ressaltar essas múltiplas dimensões configurativas e o caráter dinâmico e inter-relacional dos parques, a abordagem empreendida também perpassou paradigmas e especificidades no que se refere, por exemplo, às dimensões políticoeconômicas e histórico-culturais dos parques surgidos em cada um dos dois momentos analisados, assim como aos modos de apropriação e utilização dos mesmos pela população em suas interações com a natureza no meio urbano em ambos contextos.

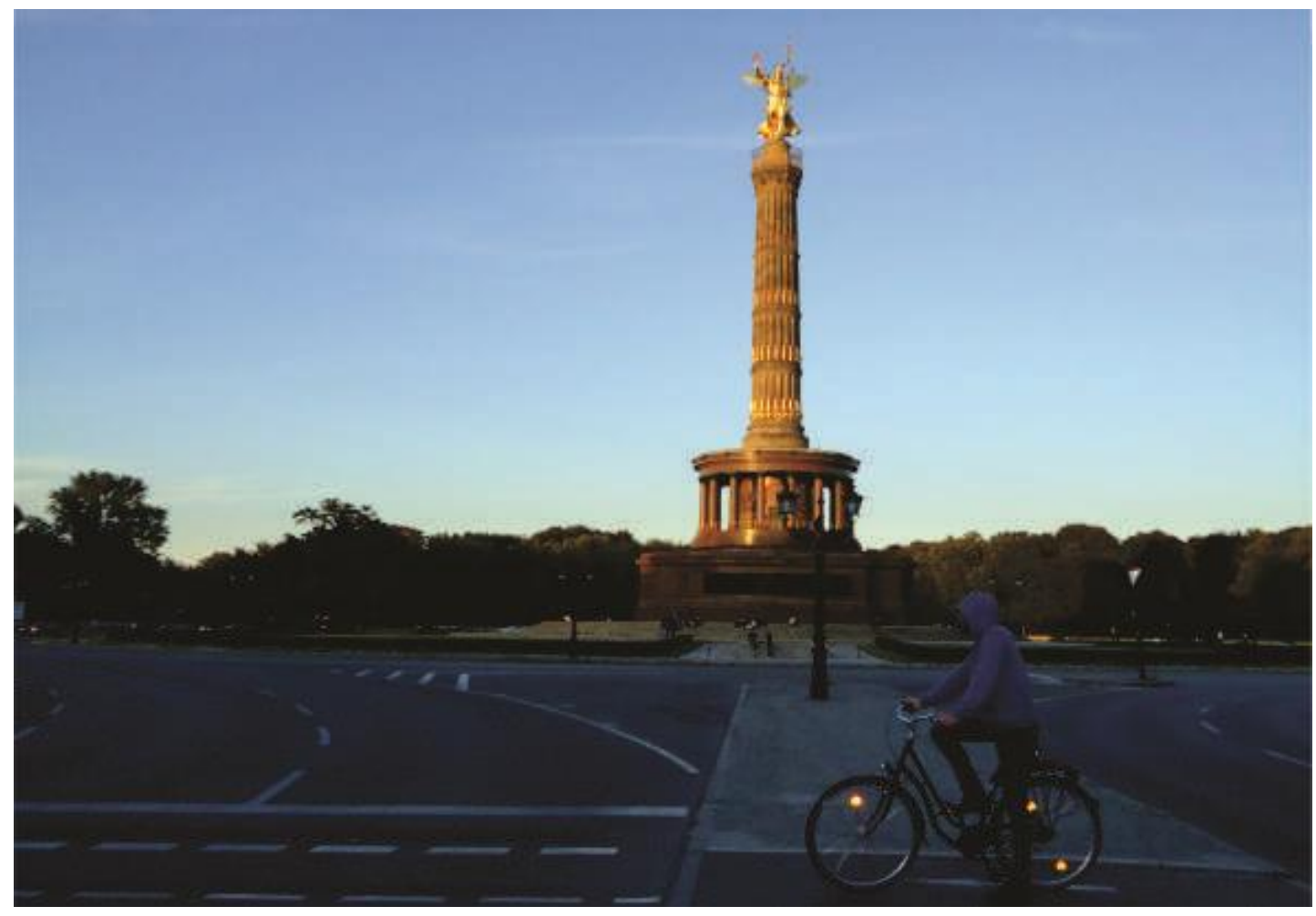

- Tiergarten em Berlim/Alemanha.

Fonte: Acervo pessoal do autor (2019). 
Especificamente, o viés político-econômico, vinculado à cristalização de espaços como o dos parques do contexto industrial, criados por meio de demolições edilícias, de reconfigurações de vazios urbanos ou da abertura ao grande público de grandes propriedades, particulares até à constuição dos Estados Nacionais, boa parte de tais espaços representaram, inicialmente, políticas de requalificação e higienização urbana, de forte controle social concretizadas mediante consideráveis investimentos monetários. Evidentemente, esta também consiste em uma dimensão de destaque nos parques emergentes no atual contexto pós-industrial, porém, em meio a crescentes crises, nas esferas ambiental, financeira e de valores, percebidas em escala global, tornam-se comuns os parques resultantes reflexões, reivindicações e políticas socioambientais ou fruto de ocupações promovidas informalmente pela sociedade civil - seja por meio de ações de moradores vizinhos a áreas verdes/livres ou de táticas de coletivos urbanos, seja até mesmo por meio de pesquisas afins, de caráter intervencionista ou de considerável influência; e é sob esse novo contexto que se observa um maior número de parques resultantes de expressões de cidadania, emergentes ou insurgentes, geralmente sem recursos econômicos significativos, o que não necessariamente implica na qualidade espacial ali alcançada e vivenciada entre as expectativas que os produziram e continuamente os transformam em vários sentidos.

Já sob o viés da representatividade histórico-cultural, também é possível perceber especificidades no âmbito dos parques representativos de cada um dois momentos abordados. Afinal, no que se refere aos parques já históricos, criados no contexto da industrialização de muitos lugares, tais espaços se consolidam como verdadeiros "pulmões da cidade" além de "inovar" as cidades por meio de sua configuração e linguagem estética então diferenciada sob vários aspectos. Já no que se refere aos parques mais recentes, criados sob o contexto pós-industrial, tais espaços se apresentam, não tanto por inovações aparentes, abruptas ou disruptivas como antes, mas sob certa "simbiose", sob referências e associações contextualistas, tanto nos casos em que se vinculam a questões e espaços contemporâneos quanto nos casos em que promovem reinterpretações, entre críticas e valorizações, de epaços já históricos - sejam espaços industriais ou mesmo anteriores a tal contexto (Fig. 20). 


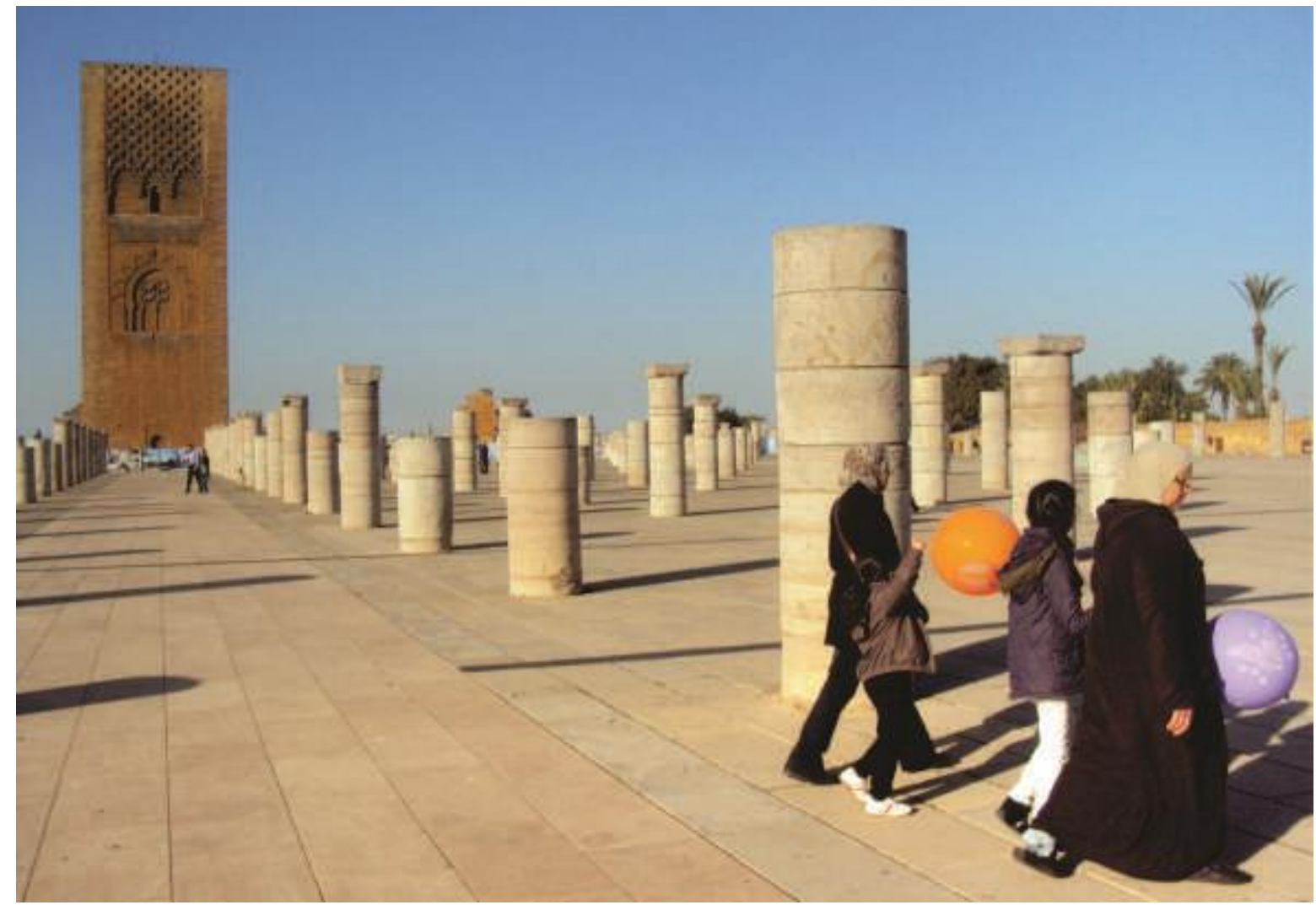

Fig. 20 Complexo de Hassan em Rabat/Marrocos.

Fonte: Acervo pessoal do autor (2012).

Por fim, no que diz respeito à utilização dos parques pela população, se a cultura dos parques foi engendrada no contexto da industrialização pela abertura ou criação de grandes áreas verdes atrativas a uma população carente de ar puro e espaços amplos e livres, ainda que sob uma liberdade vigiada, os padrões de comportamento normativo esperados e assim construídos em tais parques desde cedo se ampliaram, quando tais parques púbicos urbanos passaram a se conformar, paulatiamente, como propícios à fruição estética da paisagem, ao ócio, ao lazer, a manifestações políticas e expressões artísticas e de tantas outras vertentes. Do espaço disciplinar voltado ao operariado industrial, assim subvertido e ampliado em possibilidades tão logo foi elaborado, um espaço polivalente pode ser destacado quando nos referirmos aos parques pós-industriais, seja pela expectativa de quem hoje os cria, formal ou informalmente, seja pelas múltiplas apropriações de quem hoje busca usufruir o espaço público, crescentemente valoriado por questões ambientais, desde as últimas décadas do século XX e, almejado a partir da crise sanitária exponenciada em 2020, que potencializou tanto os atributos desses e de outros espaços amplos, abertos e livres quanto as expectativas de qualidade de vida a eles vinculada. 


\section{Considerações finais}

Outrora implantados em muitas cidades como antídoto para certos efeitos da industrialização, ainda que os parques públicos urbanos sejam, comumente, marcados pelos elementos naturais que configuram sua paisagem ou o recorte da configuração territorial que representam, sua análise os evidencia como equipamentos urbanos portadores de dimensões de significados e conhecimentos que ultrapassam, em muito, o que se pode apreender tendo como referência apenas sua dimensão material.

De facto, na abordagem aqui realizada, sob um recorte histórico abrangente e casos de referência diversificados e situados por todo o globo, foi possível enfocar algumas dessas múltiplas dimensões - como as de viés conceitual, paisagístico e heterotópico - por seu destaque em exemplares específicos. Ainda que assim acentuadas, segundo um esforço de síntese, objetivando a identificação de paradigmas e especificidades ou singularidades da categoria espacial conformada pelos parques urbanos, o evidente entrelaçamento dessas dimensões num mesmo estudo de caso permitiu que outras dimensões, também atuantes em quaisquer espaços, perpassassem a abordagem, como as de viés político-econômico, histórico-cultural e de apropriação e uso. Reforçou-se, desse modo, a compreensão da complexidade desses equipamentos como sistemas espaciais que não se limitam às suas apreensões mais superficiais, geralmente vinculadas à fruição espacial, ao lazer e ao ócio, ainda que as consideremos como experiências vitais no cotidiano citadino.

Abordar um parque urbano é considerá-lo não com um recorte estático através do tempo ou um instante congelado de um momento, mas, por sua essencia espacial, como uma esfera de múltiplas dimensões e altamente dinâmica, em processo de transformação contínua pelo facto de ser o espaço um produto de inter-relações, fruto de negociações simultâneas e sucessivas por distintas forças de interesse ali atuantes em diálogos e disputas constantes. Abordar um parque urbano em suas especificidades é reconhecer que entre intenções, estratégias e desdobramentos diversos, considerados por meio de seus discursos, suas críticas, sua espacialidade, experimentações e transformações, se delineiam muitos dos valores de seu tempo que tendem a cristalizar. 
Entre sua materialidade e sua intangibilidade, assim constatadas, ressalta-se algo mais que sua já evidente importância espacial e paisagística como um equipamento público experimentado no cotidiano de seus usuários nas mais diversas cidades. Ressalta-se, independente do momento ou da fase histórica a que se relaciona, sua potencialidade como um dispositivo ou suporte informativo das muitas dimensões que caracterizam as contradições e dialéticas de nossas reflexões e ações.

\section{Referências}

ASSIS, Joaquim Maria Machado de. O século dos jardins. In: SEGAWA, Hugo. Ao amor do público: jardins no Brasil. São Paulo: Studio Nobel, FAPESP, 1996.

BAUDELAIRE, Charles. As flores do mal. Rio de Janeiro: Nova Fronteira, 1985.

BELL, Daniel. O advento da sociedade pós-industrial. São Paulo: Cultrix, 1977.

BENJAMIN, Walter. Espaços que suscitam sonhos: museus, pavilhões de fontes hidrominerais. Revista do Patrimônio. MinC/IPHAN. Brasília, 2005, n. 31, pp. 132-147.

BENJOR, Jorge. Salve o verde. In: CY, Quarteto em. Querelas do Brasil. Rio de Janeiro: Philips, 1978. Lado B, faixa 1. Disco de vinil.

CHOAY, Françoise. O urbanismo. São Paulo: Perspectiva, 2018.

CLÉMENT, Gilles. Traité succinct de l'art involontaire. Paris: Sens \& Tonka, 1997.

COUTINHO, Evaldo. O espaço da arquitetura. São Paulo: Perspectiva, 2010.

FARIELLO, Francesco. Lar arquitectura de los jardines: de la Antiguidad al siglo XX. Barcelona: Reverte, 2008.

FERNANDES, Bernardo Mançano. Movimentos socioterritoriais e movimentos socioespaciais : contribuição teórica para uma leitura geográfica dos movimentos sociais. OSAL: Observatório Social de América Latina. Ano 6, n.16. Buenos Aires: CLACSO, 2005.

FOUCAULT, Michel. Outros espaços. In: MOTTA, Manoel Barros da (Org.). Michel Foucault - Ditos e Escritos. Estética: literatura e pintura, música e cinema. v.3. Rio de Janeiro: Forense Universitária, 2009, p. 411-422.

GLASS, Ruth. London: aspects of change. Londres: MacGibbon \& Kee, 1964.

GOULD, K. A.; LEWIS, T. L. Green gentrification: urban sustainability and the struggle for environmental justice. London and New York: Routledge, 2017.

JODIDIO, Philip. Arquitectura hoy! v. 4. Barcelona: Taschen, 2006.

HOWARD, Ebenezer. Cidades-jardins de amanhã. São Paulo: Hucitec, 2012.

LEFEBVRE, Henri. La producción del espacio. Madrid: Capitán Swing, 2013.

MARCUSE, Herbert. Ideologia da Sociedade Industrial: o homem unidimensional. Rio de Janeiro: Jorge Zahar, 1973.

MASSEY, Doreen. Pelo espaço: uma nova política da espacialidade. Rio de Janeiro: Bertrand Brasil, 2008.

MONEO, Rafael. Inquietação teórica e estratégia projetual. São Paulo: Cosac \& Naify, 2008.

MOORE, Kathryn. A cultura da natureza. In: MOSTAFAVI, Mohsen; DOHERTY, Gareth (Orgs.). Urbanismo Ecológico. São Paulo: Gustavo Gili, 2014. 
PANZINI, Franco. Projetar a natureza: arquitetura da paisagem e dos jardins desde as origens até a época contemporânea. São Paulo: SENAC, 2013.

PESSOA, Fernando. Obra Poética de Fernando Pessoa. Rio de Janeiro: Nova Fronteira, 2016.

RAJA, Raffaele. Arquitetura pós-industrial. São Paulo: Perspectiva, 1993.

RIO, João do. A alma encantadora das ruas. São Paulo: Martin Claret, 2013.

SANTOS, Milton. A natureza do espaço. São Paulo: Edusp, 2008.

SEGAWA, Hugo. Ao amor do público: jardins no Brasil. São Paulo: Studio Nobel, FAPESP, 1996.

SMITHSON, Robert. Monuments of Passaic. Artforum. Nova York, dez. 1967, pp. 52-57.

TARANOVSKAYA, M. Z. Carl Rossi. Architect. Town-planner. Artist. Leningrad: Stroiizdat, 1980.

TSCHUMI, Bernard. Six concepts. In: READ, A. (org.). Architecturally speaking: pratices of art, architecture and the everyday. Londres: Routledge, 2000, pp. 155-176.

ZEVI, Bruno. Architectura in Nuce: uma definição de arquitetura. Lisboa: Edições 70, 1986. 